\title{
"Second or Successive" Habeas Petitions and Late-Ripening Claims after Panetti v Quarterman
}

\author{
Kyle P. Reynolds $\dagger$
}

\section{INTRODUCTION}

The Antiterrorism and Effective Death Penalty Act of $1996^{1}$ (AEDPA) provides that, except in narrow circumstances, "second or successive" petitions for writs of habeas corpus must be dismissed. Some valid constitutional claims, however, do not become ripe until after the prisoner has been convicted and sentenced, and perhaps after one habeas petition has been presented and denied on the merits. AEDPA's "gatekeeping" provisions - codified at 28 USC $\$ 2244$ (b) have the potential to foreclose review of meritorious constitutional claims, and a division in the circuit courts has developed over their interpretation. One set of courts takes a "liberal" approach, focusing on pre-AEDPA common law principles and erring on the side of allowing claims. Another set takes a more rigorous textual and structural tack, which is appealing on an interpretive level but has the potential to prevent judicial review of constitutional violations. The $\mathrm{Su}$ preme Court has recently addressed a limited aspect of this question, and it applied the liberal approach with a pragmatist flourish. All of these approaches suffer from serious shortcomings, and this Comment argues that the textual interpretation should be followed except in certain circumstances in which that interpretation would foreclose review of a possible constitutional violation. In this scenario, courts should invoke the canon of constitutional avoidance to prevent violating the underlying constitutional right that the prisoner seeks to vindicate through a writ of habeas corpus.

In short, this Comment focuses on a very particular question, but one that could be of great import. Imagine a prisoner petitions a federal court for a writ of habeas corpus, and the petition is duly adjudicated on the merits. If she files again, this time including a claim that was unripe at the time of the earlier petition and thus not included, must the chronologically second petition be dismissed as "second or

$\dagger$ BA 2003, Kalamazoo College; JD Candidate 2008, The University of Chicago.

1 Pub L No 104-132, 110 Stat 1214, codified in relevant part at 28 USC $\$ 2241$ et seq (2000 \& Supp 2004).

2 See 28 USC $\$ 2244$ (b). 
successive" under AEDPA? Or, in the parlance often extended to this issue, should the prisoner receive another "bite at the apple" when AEDPA appears to allow only one?

This Comment is divided into six Parts. Part I presents AEDPA, paying particular attention to the changes it made to existing habeas procedure. Part II surveys recent Supreme Court decisions relevant to this discussion. Part III presents the circuit split over the interpretation of the "second or successive" clauses. Part IV presents a recent Supreme Court case that partially-but neither satisfactorily nor entirely-addresses this split. Part V explains why the current state of the law is undesirable and examines some alternatives to AEDPA that prisoners might attempt to use to have their claims reviewed. Part VI first argues for a theoretical identification of rights and remedies as an inseparable unity and then articulates potential constitutional problems that come from one of the interpretive approaches to $\S 2244$ (b). A solution to this split is then proposed that focuses on the application of the canon of constitutional avoidance and the potential violation of constitutional rights in cases where AEDPA is construed to foreclose any judicial remedy for late-ripening claims. This Part concludes with some general reflections on the impact of this proposal.

\section{AEDPA: A BASIC HISTORY AND OVERVIEW}

The writ of habeas corpus bears a pedigree extending back many hundreds of years to the toddlerhood of the English common law. ${ }^{3}$ The United States Constitution protects against its suspension except in extraordinary circumstances, ${ }^{4}$ and the writ's contours have been tweaked numerous times by both the judiciary and the legislature of the United States. As a common law creation, it was governed by common law rules-specifically, a rule referred to as "abuse of the writ." This rule, too, was the product of incremental development. In fact, "[a]t common law, res judicata did not attach to a court's denial of

3 Throughout this Comment, the terms "habeas" and "habeas corpus" refer to the common law writ of habeas corpus ad subjiciendum, in contrast to other, lesser writs. For a discussion of the English common law history of the writ, see William F. Duker, A Constitutional History of Habeas Corpus 3-5, 12-63 (Greenwood 1980) (tracing the writ's development through the seventeenth century). No less a figure than William Blackstone noted that the writ was "frequently considered as another magna carta." William Blackstone, 3 Commentaries on the Laws of England $* 135$ (Chicago 1979).

4 See US Const Art I, $\$ 9, \mathrm{cl} 2$ ("The Privilege of the Writ of Habeas Corpus shall not be suspended, unless when in Cases of Rebellion or Invasion the public Safety may require it."). This has come to be known in constitutional shorthand as the "Suspension Clause."

5 See McCleskey $v$ Zant, 499 US 467, 470 (1991) ("The doctrine of abuse of the writ defines the circumstances in which federal courts decline to entertain a claim presented for the first time in a second or subsequent petition for a writ of habeas corpus."). 
habeas relief." The reason for this was that "since no appeal against a refusal to issue the writ ... was available, it would have been intolerable for a person to have the legality of his custody determined conclusively by the first judicial body to hear the matter."'

The abuse-of-the-writ doctrine in the United States eventually allowed for judicial discretion over whether a particular claim could go forward. In particular, a pair of cases from the 1920s reaffirmed that res judicata did not apply to habeas relief, but since appellate review was now available, endless claims could scarcely be tolerated. ${ }^{8}$ The Supreme Court remarked that

[i]n early times when a refusal to discharge was not open to appellate review, courts and judges were accustomed to exercise an independent judgment on each successive application, regardless of the number. But when a right to an appellate review was given the reason for that practice ceased and the practice came to be materially changed.

The Court decided on a deferential but nebulous standard. In entertaining habeas petitions, courts should allow second or successive claims "to be disposed of in the exercise of a sound judicial discretion guided and controlled by a consideration of whatever has a rational bearing on the propriety of the discharge sought." could have raised a claim in the first hearing, but had no reason for declining to do so, could not bring it in a second petition without running afoul of the abuse-of-the-writ doctrine. ${ }^{11}$ Generally, petitions that raised claims that were made earlier and were filed in bad faith - that is, tending to cause delay-were blocked. ${ }^{12}$ A gradual expansion of habeas jurisdiction led to legislation addressing the issue of repeated frivolous, feeble, and dilatory petitions for the writ. ${ }^{13}$ Finally, before

6 Id at 479

7 Duker, A Constitutional History of Habeas Corpus at 5-6 (cited in note 3).

8 See Wong Doo $v$ United States, 265 US 239, 241 (1924) (allowing lower courts hearing successive habeas claims to give "controlling weight ... to the prior refusal"); Salinger v Loisel, 265 US 224, 230-31 (1924) (noting that "comprehensive review in criminal cases" also narrowed the scope of claims cognizable under habeas).

9 Salinger, 265 US at 230-31.

10 Id at 231.

11 See Wong Doo, 265 US at 241 ("To reserve the proof for use in attempting to support a second petition, if the first failed, was to make an abusive use of the writ.").

12 See Randy Hertz and James S. Liebman, 2 Federal Habeas Corpus Practice and Procedure $\$ 28.2$ (b) at 1403-04 (LexisNexis 5th ed 2005) (tracing the shift from judicial to statutory standards of habeas review).

13 See, for example, Sanders v United States, 373 US 1, 11 (1963) ("[A]s part of the 1948 revision of the Judicial Code, the Court's statement in Salinger ... was given statutory form."). 
AEDPA's enactment, American courts predominantly relied on a standard of judicial discretion to address the problem."

\section{A. Origins and Antecedents of AEDPA}

This reliance on judicial discretion, however, was about to change dramatically. The standard telling of the story goes something like this: The year is 1996, and in Congress, the issue of national security crackles with urgency. One year prior, two men and a truck packed with fertilizer transformed an Oklahoma federal building into a grotesque and concave shell. ${ }^{15}$ Two years before that, an underground parking garage in New York City's World Trade Center was hollowed out by another truck bomb that evaded the building's security. ${ }^{16}$ The obligatory editorials ensued, detailing how the horrors of Beirut, Belfast, Jerusalem, and Sarajevo had come to American shores. ${ }^{17}$ In a series of ongoing and seemingly more pedestrian occurrences, federal courts are continually besieged by state prisoners filing frivolous petitions for habeas corpus. ${ }^{18}$ From this context-hideous sorties from enemies

14 See 28 USC $\$ 2254$ Rule 9(b) (1976) (permitting judges to dismiss a "second or successive petition" that implicates abuse of the writ). See also McCleskey, 499 US at 483-84 ("[A]s a general matter Congress did not intend the new section to disrupt the judicial evolution of habeas principles."). This Part gives short shrift to the history of the doctrine in the United States, but does provide an example of early standards. Throughout most of the last century, the standard was in flux, and it is thus difficult to encapsulate the doctrine across time. For a fuller explication, see Hertz and Liebman, 2 Federal Habeas Corpus Practice and Procedure \$28.2(b) at 1403-07 (cited in note 12); McCleskey, 499 US at 479-89.

15 See John Kifner, Terror in Oklahoma City, NY Times A1 (Apr 20, 1995); Sue Anne Pressley, Bomb Kills Dozens in Oklahoma Federal Building, Wash Post A1 (Apr 20, 1995).

16 See Robert D. McFadden, Explosion at the Twin Towers, NY Times A1 (Feb 27, 1993) (describing the scope of the destruction caused by the explosion); Malcolm Gladwell, At Least 5 Die, 500 Hurt as Explosion Rips Garage under World Trade Center, Wash Post A1 (Feb 27, 1993) (discussing possible reasons for the bombing).

17 See, for example, Jim Hoagland, On Guard, People, Wash Post A27 (Apr 21, 1995) ("Similar 'statements' have been written in the car-bombed buildings on both sides of the line dividing Christian and Muslim Beirut, the firebombed buses of Israel and in the wreckage of a dozen other conflicts of recent years."); Editorial, Savagery in Oklahoma City, NY Times A22 (Apr 20, 1995) ("A fate like Beirut's Americans and their Government must never tolerate.").

18 See, for example, Excerpts from Rehnquist Speech Urging Curb on Death Penalty Appeals, NY Times A18 (May 16, 1990) ("The system at present verges on the chaotic."); Lewis F. Powell, Jr., Capital Punishment, 102 Harv L Rev 1035, 1035 (1989) ("[O]ur present system of multi-layered appeals has led to excessively repetitious litigation and years of delay between sentencing and execution."); Herbert Wechsler, Habeas Corpus and the Supreme Court: Reconsidering the Reach of the Great Writ, 59 U Colo L Rev 167, 180 (1988) ("Federal judges are by no means happy with the inundation of their courts by [habeas] filings, even though the great preponderance can be dismissed without an evidentiary hearing."); Henry J. Friendly, Is Innocence Irrelevant? Collateral Attack on Criminal Judgments, 38 U Chi L Rev 142, 148 (1970) ("[T]he most serious evil with today's proliferation of collateral attack is its drain upon the resources of the community."). This concern was neither new nor unknown to the United States Reporter. See Brown v Allen, 344 US 443, 536-37 (1953) (Jackson concurring): 
both foreign and domestic, courts on the verge of impotence to enforce serious penalties-AEDPA was born.

But as with most standard stories, this one only gets it half right. Far from having a unitary purpose adapted to particular circumstances, AEDPA was a piece of long-contemplated compromise legislation passed by a divided government. Its seeds can be seen in President Reagan's 1985 State of the Union Address, and some of its basic ideas were included in the 1994 Republican "Contract with America." The debates over the bill were far-reaching, ${ }^{21}$ but were held under the threat of a presidential veto. ${ }^{22}$ Some Congressmen yearned to launch a full-scale assault on the writ; others desired no change at all. The result, which ended up gaining a fair portion of support, was clearly a hard-earned compromise, and it is difficult to say with any specificity what the unitary purpose of the bill was.

But it cannot be denied that, if AEDPA can be said to have any purposes at all, one such purpose would be to restrict the filing of frivolous habeas petitions that are disruptive of judicial finality and parasitic upon official time. To this end, AEDPA directs district courts to dismiss any claim "in a second or successive habeas corpus application ... that was presented in a prior application," weren't presented in an earlier petition-only to allow them under

[T]his Court has sanctioned progressive trivialization of the writ until floods of stale, frivolous and repetitious petitions inundate the docket of the lower courts and swell our own.... It must prejudice the occasional meritorious application to be buried in a flood of worthless ones. He who must search a haystack for a needle is likely to end up with the attitude that the needle is not worth the search.

19 See State of the Union: "Second American Revolution," NY Times B8 (Feb 7, 1985) ("I urge the House to follow the Senate and enact proposals ... reform[ing] the habeas corpus laws and allow[ing] ... the use of the death penalty where necessary.").

20 See Hobart Rowen, The Contract: Shall It Come to Pass?, Wash Post A23 (Nov 17, 1994) (describing Republican legislation that would curb abuse of criminal appeals and increase use of the death penalty).

21 Senator Bob Dole, a sponsor of the bill, remarked upon the proposed legislation that "[t]he most critical element of this bill, the one that bears most directly on the tragic events in Oklahoma City, is the provision reforming the so-called habeas corpus rules" 104th Cong, 1st Sess (June 5, 1995), in 141 Cong Rec S 7877 (June 7, 1995). This stands in stark contrast to the statements of Representative Don Young, who noted that "this legislation is a knee-jerk reaction to a most heinous crime. This body has passed enough legislation in previous years to catch and punish criminals who commit these atrocious acts against humanity," 104th Cong, 2d Sess (Apr 18, 1996), in 142 Cong Rec E 638 (Apr 25, 1996), and Howard Berman, who stated, "Shame on those who invoke the names of innocents slaughtered in Oklahoma City ... in their quest to effectively abolish the writ of habeas corpus," id at H 3610 (Apr 18, 1996).

22 See Katharine Q. Seelye, Anti-Crime Bill as Political Dispute, NY Times A16 (Feb 21, 1995) (noting that President Clinton's veto pledge was his first "against a specific piece of legislation").

2328 USC $\$ 2244(\mathrm{~b})(1)$. 
certain restricted circumstances. ${ }^{24}$ The phrase "second or successive," however, is not defined anywhere in the act, and there are a number of questions about its interpretation that remain open. ${ }^{25}$

B. Specific Provisions of the Act and Changes Wrought on Existing Habeas Procedure

AEDPA is a wide-ranging act that touches on a variety of different aspects of national security and criminal justice. The relevant sections for the purposes of this Comment are those that reform habeas corpus practice. These were codified in Title 28 of the United States Code.

Section 2254(a) authorizes justices and judges to entertain applications for habeas corpus for those incarcerated in state court. It declares that

[t]he Supreme Court, a Justice thereof, a circuit judge, or a district court shall entertain an application for a writ of habeas corpus in behalf of a person in custody pursuant to the judgment of a State court only on the ground that he is in custody in violation of the Constitution or laws or treaties of the United States.

This section was left untouched by AEDPA. A different part of that same section, however, made the standard by which federal courts evaluate the decisions of their state counterparts much stricter. Section 2254(d) was inserted as a result of AEDPA. That section reads as follows:

An application for a writ of habeas corpus on behalf of a person in custody pursuant to the judgment of a State court shall not be granted with respect to any claim that was adjudicated on the merits in State court proceedings unless the adjudication of the claim-

(1) resulted in a decision that was contrary to, or involved an unreasonable application of, clearly established Federal law, as determined by the Supreme Court of the United States; or

(2) resulted in a decision that was based on an unreasonable determination of the facts in light of the evidence presented in the State court proceeding.

This represents a significant change in how federal courts evaluated habeas petitions by state prisoners whose claims had been previously adjudicated on the merits in state court. The law under which the

2428 USC $\$ 2244$ (b)(2) (listing a retroactive change in constitutional interpretation as one such circumstance). See also Part I.B.

25 See Part I.C. 
incarcerated were held in violation must now be clearly established, and it must have been so established by a Supreme Court decision. ${ }^{26}$

What was eventually codified in $\$ 2244$ represents the most significant change for the purposes of this analysis. That section limited "second or successive" habeas petitions except in certain circumstances. The relevant part reads:

(b)(1) A claim presented in a second or successive habeas corpus application under section 2254 that was presented in a prior application shall be dismissed.

(2) A claim presented in a second or successive habeas corpus application under section 2254 that was not presented in a prior application shall be dismissed unless-

(A) the applicant shows that the claim relies on a new rule of constitutional law, made retroactive to cases on collateral review by the Supreme Court, that was previously unavailable; or

(B)(i) the factual predicate for the claim could not have been discovered previously through the exercise of due diligence; and

(ii) the facts underlying the claim, if proven and viewed in light of the evidence as a whole, would be sufficient to establish by clear and convincing evidence that, but for constitutional error, no reasonable factfinder would have found the applicant guilty of the underlying offense. ${ }^{27}$

The "and" between subsections (2)(B)(i) and (2)(B)(ii), while easy to overlook, is particularly salient for habeas procedure. Under the current statutory framework, a petitioner can bring a claim based on a new factual predicate, but only if these facts establish lack of guilt as to the underlying offense beyond a high standard. This section effectively blocks petitions based upon new factual predicates that do not clear the prisoner of the original conviction. ${ }^{28}$

26 This refers to the time of adjudication in the state court. Before AEDPA, state courts were required to apply federal law-not just Supreme Court precedents-through the end of direct review. Except in limited circumstances, cases that had completed direct review and moved on to collateral review could not benefit from the retroactivity of "new" constitutional rules. See Teague $v$ Lane, 489 US 288, 310 (1989) (arguing that retroactivity "continually forces the States to marshal resources in order to keep in prison defendants whose trials and appeals conformed to then-existing constitutional standards"). For a discussion of what constitutes an "unreasonable application" of clearly established law, see Williams v Taylor, 529 US 362, 407-09 (2000) (identifying inapt applications of valid legal principles to specific facts and inappropriate extensions of legal principles as two instances of unreasonable applications of Supreme Court precedent).

2728 USC $\$ 2244$ (b).

28 This concept is explored in greater depth in Part V.A. 
In order to surmount these "gatekeeping" provisions of $\$ 2244(b)(2)$, a prisoner must make a motion before a three-judge panel of the relevant court of appeals. ${ }^{29}$ If the panel determines that the prisoner's petition qualifies under $\S 2244$, it may issue an order directing the district court to entertain the application. ${ }^{30}$ The decision of the three-judge panel is final; it cannot be appealed to the Supreme Court or be the subject of a petition for certiorari. ${ }^{31}$ In other words, neither the prisoner nor the state can seek to disrupt the judgment of the panel. But if the panel determines that the petition fails to meet the requirements listed in $\$ 2244$, it is to dismiss the petition. ${ }^{32}$ The statute speaks for itself in many respects, but the scope of the changes to pre-AEDPA habeas procedure is unclear. Certain questions can and must be teased out of the statute's interstices-questions that have no clear answers from the text.

\section{A Few Unanswered Questions}

Once again, AEDPA does not speak for itself quite as articulately as one would like, and significant questions about its effects have come before the courts. It is difficult to say with precision exactly what changes AEDPA made to habeas practice with respect to certain issues.

First, § 2244 speaks of "second or successive" petitions, but declines to define this term. What does it mean? Does the "plain meaning" control, insofar as the phrase applies to any federal habeas petition after the first? Or is this phrase a term of art that means something else entirely? Is it intended to incorporate specifics of habeas practice that were regnant before the change? The statute is silent on these issues.

Secondly, what of the pre-AEDPA common law rules, specifically the abuse-of-the-writ doctrine that had been partially resurrected by the Supreme Court? ${ }^{33}$ It can be contended, though not without difficulty, that AEDPA is a completely self-interpreting statute and entirely supplanted the equitable principles that courts employed earlier. Another reasonable contention is that the tools that courts used to approach habeas petitions before the act are still valid, and that the phrase "second or successive" should be approached with the abuseof-the-writ doctrine in mind. Supreme Court decisions have not inter-

\footnotetext{
28 USC $\S 2244$ (b)(3)(A)-(B).

28 USC $\$ 2244$ (b)(3)(C).

28 USC \& 2244(b)(3)(E).

28 USC $\$ 2244$ (b)(4).

See Part II.A.
} 
preted the text in the narrowest manner, ${ }^{34}$ and the tension between the pre-AEDPA principles and the text of $\S 2244$ remains.

A third question, and one of singular importance, is how courts are to navigate these issues without running afoul of the United States Constitution. As noted previously, the writ of habeas corpus is mentioned by name in the Constitution, with the proviso that it not be "suspended." Furthermore, habeas is a vehicle for the vindication of other constitutional rights. In enforcing AEDPA, how can judges be sure that they are not acting in a manner repugnant to the Constitution or violating the constitutionally protected rights of prisoners?

The final unanswered question is precise: if a prisoner files for a writ of habeas corpus that is adjudicated on the merits, and then she files again, this time including a claim that was factually unripe at the time of the earlier petition and thus not included, is the chronologically second petition considered "second or successive" for purposes of AEDPA?

The Supreme Court has faced these kinds of questions since the enactment of AEDPA, and an understanding of how it approached the first three questions will inform the analysis of the last.

\section{RECENT SUPREME COURT DECISIONS INTERPRETING AEDPA'S "SECOND OR SUCCESSIVE" CLAUSES}

For a mere commentator to engage in statutory interpretation on such a microlevel might seem almost self-indulgently stale and recondite. But when the subject is a procedural mechanism "[c]onsidered by the Founders as the highest safeguard of liberty," ${ }^{, 35}$ the stakes seem substantially greater. This Comment is obviously not the first inquiry into the "second or successive" provisions. The United States Supreme Court has been presented with interpretive questions about AEDPA; these cases must substantially inform any attempt to parse the act.

\section{A. Felker v Turpin}

The Supreme Court's first foray into AEDPA came in 1996, very shortly after the act itself was passed. ${ }^{37}$ In Felker, the Court entertained, among other claims, a broad attack on the constitutionality of AEDPA. In the ensuing opinion, a unanimous Court held that

\footnotetext{
See Part II.B.

Smith v Bennett, 365 US 708, 712 (1961).

518 US 651 (1996).

37 President Clinton signed AEDPA into law on April 24, 1996. 110 Stat at 1214. Felker was handed down on June 28 of that same year. 518 US at 651 .
} 
AEDPA did not violate the Suspension Clause of the Constitution. Petitioners who are unable to file claims in federal district court because of AEDPA's "second or successive" clauses are still free to file for an original writ of habeas corpus in the Supreme Court. Relying on the 1868 case of Ex Parte Yerger, the court found that Title I of the Act did not deprive the Court of the authority to entertain original habeas petitions. ${ }^{40}$

The Court then assessed the impact of this finding in combination with an analysis of a potential Suspension Clause violation. The opinion's brief historical survey of the scope of the habeas writ demonstrates that the writ's coverage had expanded dramatically since the founding." Assuming that "the Suspension Clause of the Constitution refers to the writ as it exists today, rather than as it existed in $1789, "$, the court found that the restrictions placed upon the writ fell into the category of "judgments about the proper scope of the writ" that are "normally for Congress to make."

With respect to the "abuse of the writ" doctrine, the Court fully acknowledged the doctrine's continued relevance, noting that "[ $t]$ he new restrictions on successive petitions constitute a modified res judicata rule, a restraint on what is called in habeas corpus practice 'abuse of the writ." ${ }^{45}$ This doctrine "refers to a complex and evolving body of equitable principles informed and controlled by historical usage, statutory developments, and judicial decisions." "46 AEDPA's newly imposed restrictions are fully a part of this process, and thus the act does not violate the Suspension Clause.

\section{B. Stewart $v$ Martinez-Villareal ${ }^{48}$}

Less than two years elapsed before the Court was confronted with another issue arising out of AEDPA. Martinez-Villareal involved

\footnotetext{
38 See Felker, 518 US at 653-54 ("[T]he Act does not preclude this Court from entertaining an application for habeas corpus relief, although it does affect the standards governing the granting of such relief").

3975 US (8 Wall) $85,105-06$ (1868) (upholding a statute that repealed a year-old grant of extended habeas jurisdiction to the Court).

40 See Felker, 518 US at 658-61 (noting, however, that "the Act does impose new conditions on [the Court's] authority to grant relief").

41 Id at 663-64 ("The writ of habeas corpus known to the Framers was quite different from that which exists today."). See also Part I.

42 Id at 663-64.

43 See id at 664.

44 Id, quoting Lonchar v Thomas, 517 US 314, 323 (1996).

45 Felker, 518 US at 664.

46 Id, quoting McCleskey v Zant, 499 US 467, 489 (1991).

47 Felker, 518 US at 664.

48523 US 637 (1998).
} 
a prisoner whose Ford $v$ Wainwright ${ }^{49}$ claim of psychiatric incompetence in his initial habeas petition was denied for failure to exhaust state remedies; ${ }^{50}$ he duly refiled once he had done so. The district court held that he must apply to the court of appeals, and that court held that the petition was not "second or successive." Supreme Court noted that no case had ever held that a petition like the one presented should be marked as "second or successive" merely because it was earlier dismissed for failure to exhaust state remedies. An ominous discontinuity between two readings of the text was thus exposed: taken literally, the prisoner's claim was "presented" in a prior application, and should be dismissed. ${ }^{53}$ But the Court took another approach. The majority noted that

[t]his may have been the second time that respondent had asked the federal courts to provide relief on his Ford claim, but this does not mean that there were two separate applications, the second of which was necessarily subject to $\S 2244$ (b). There was only one application for habeas relief, and the District Court ruled (or should have ruled) on each claim at the time it became ripe.

Should the alternate interpretation be adopted, "the implications for habeas practice would be far reaching and seemingly perverse." "s5

Rather than taking the plain textual approach of the dissenters, the Court found a way to preserve the prisoner's Ford claim, which would not have become ripe until his execution was imminent. ${ }^{\text {s6 }}$ The textual approach would also mean that a technical procedural error or misunderstanding would render habeas review by federal courts unavailable. ${ }^{\text {.7 }}$ It can be argued that the conclusion of this case was driven

49477 US $399,409-10$ (1986) (holding that "the underlying social values encompassed by the Eighth Amendment" prohibit the execution of those with "no capacity").

50 See Martinez-Villareal, 523 US at 640 (noting that all three of the prisoner's petitions were dismissed).

51 Id at $640-41$. Moving in the court of appeals is required by 28 USC $\$ 2244$ (b)(3). See Part I.B.

52 Martinez-Villareal, 523 US at 644 (describing the primacy of state court remedies as "reflect[ing] a policy of federal-state comity").

53 See id at 646 (Scalia dissenting) (" $[\mathrm{I}] \mathrm{t}$ is impossible to conceive of language that more clearly precludes respondent's renewed competency-to-be-executed claim than the written law before us here."). See also id at 648-50 (Thomas dissenting) (interpreting the "plain meaning" of the statute with reference to dictionary definitions).

54 Id at 643 (majority).

55 Id at 644 .

56 The execution was not considered imminent while state remedies were still available. See id at $644-45$.

57 Id at 645 (including, for example, the failure to pay filing fees). The court expressly declined to entertain a scenario somewhat similar to that envisioned by this Comment - "where a prisoner raises a Ford claim for the first time in a petition filed after the federal courts have 
by an attempt to avoid the serious constitutional question that would arise if the Court had followed the plain meaning of the text, ${ }^{58}$ which left the circuit courts with a tension between AEDPA's text and its purported intent.

\section{THE INTERPRETIVE DISPUTE IN THE CIRCUIT COURTS}

The Supreme Court does not monopolize this discussion. This issue has faced the federal circuit courts on a number of occasions, with varying results. It is essential to remember that these decisions were handed down before the recent Supreme Court decision Panetti $v$ Quarterman, ${ }^{\circ}$ but after Martinez-Villareal, which allowed for a textual departure to effectuate what the Court thought to be AEDPA's purpose. As such, the tension between textualism and purposivism that was made clear in Martinez-Villareal is reflected in the lower court decisions. In that case, however, the petitioner's initial habeas petition was dismissed for procedural reasons - in all of the following cases, the initial petition was adjudicated on the merits. When these decisions are surveyed, two general strands emerge: one that allows newly ripe claims to be presented even though the earlier petition was adjudicated on the merits and one that does not. Each will be examined in turn and later compared against the partial resolution of Panetti.

already rejected the prisoner's initial habeas application." Id at $645 \mathrm{n}$ *. Additionally, this issue, explicitly set aside in Martinez-Villareal, was decided by the Court in Panetti $v$ Quarterman, $127 \mathrm{~S}$ Ct 2842 (2007), which will be discussed in Part IV.A. Another notable case handed down before Panetti, but after Martinez-Villareal, is Slack v McDaniel, 529 US 473 (2000), in which the Court reiterated its interpretation of $\S 2244$ from Martinez-Villareal when dealing with a petition that had been dismissed during the initial round for failure to exhaust state remedies. See id at 487 ("A petition filed after a mixed petition ... is to be treated as 'any other petition' and is not a second or successive petition."). See also Rose v Lundy, 455 US 509, 510 (1982) (holding that “mixed petitions"- those containing both claims that have been exhausted in state court and claims that have not been so exhausted-must be dismissed in whole by federal courts). The Court in Slack demonstrably declined to state that the meaning of "second or successive" would be different under the AEDPA rules. See 529 US at 486. In fact, "[ $t$ ]he phrase 'second or successive petition' is a term of art given in [the Supreme Court's] prior habeas corpus cases." Id. While acknowledging "second or successive" as a "term of art," the court nonetheless failed to say precisely what the term means. But one thing is clear: the text of the Act does not control insofar as it absolutely requires the dismissal of any claim presented in a second or successive petition that had been presented earlier.

58 See Part VI.B.

59 The Court has been confronted with similar issues at least three times in 2007. In Burton $v$ Stewart, 127 S Ct 793 (2007) (per curiam), the court held that a prisoner who filed a petition, knowing that other claims were unexhausted, could not bring those claims later, despite the fact that he may have had a "legitimate excuse" for doing so. See id at 796-97, 799. The Court also denied certiorari to a case presenting an issue very similar to the one analyzed in this Comment. Lambert v Buss, 127 S Ct 1814 (2007). The Seventh Circuit's decision in Lambert is examined in Part III.B. The issue declined in Lambert was taken up in Panetti merely a few months later. See Part IV.A.

$60127 \mathrm{~S} \mathrm{Ct} 2842$ (2007). 
A. The Lower Courts: Petitions Containing Subsequent and Newly Ripened Claims Are Not Necessarily "Second or Successive"

The majority of the lower courts facing this issue have held that, once an initial petition is adjudicated on the merits, a petition containing a claim that has ripened in the meantime is not necessarily "second or successive" under AEDPA. These cases and claims arose in a number of contexts, but the common thread is that they were not dismissed under $\$ 2244(b)$.

The Second Circuit faced this issue in James $v$ Walsh. ${ }^{61}$ After filing a habeas petition that was denied on the merits, the petitioner filed yet another petition, this time alleging that the corrections department had miscalculated his sentence, and that he was being held in violation of state and federal law. ${ }^{62}$ After the district court transferred the case to the court of appeals, the Second Circuit noted the marked disinclination of courts to adopt a literal reading of $\$ 2244$, and that a chronologically second petition need not be considered a statutorily second petition under that section. ${ }^{63}$ It also supplied a definition: "Under the abuse-of-the-writ doctrine, a subsequent petition is 'second or successive' when it raises a claim that was, or could have been, raised in an earlier petition." ${ }^{64}$ Because the petitioner could not have challenged the administration of his sentence in the prior petition, it would be considered a "first" petition as to that claim, even though it was second chronologically.

The Third Circuit reached a similar conclusion on similar facts in Benchoff $v$ Colleran. ${ }^{66}$ In that case, the petitioner collaterally attacked his conviction on habeas review, and after that petition was denied, he filed another, alleging due process violations because he was not provided with reasons for parole denial. ${ }^{67}$ The court of appeals raised the $\$ 2244(b)$ issue sua sponte and noted that the other courts of appeals have "uniformly" approached the "second or successive" language with reference to the abuse-of-the-writ principles developed before

\footnotetext{
61308 F3d 162 (2d Cir 2002).

62 Id at 165 . Note that 28 USC $\$ 2254$ (a) allows only federal judges to review state court proceedings on the ground that the prisoner "is in custody in violation of the Constitution or laws or treaties of the United States" (emphasis added).

63 See James, 308 F3d at 165, 167.

64 Id at 167.

65 Id at 168 ("[The petitioner] could not have argued that he was in custody in violation of the laws of the United States before the time when, according to his calculations, he should have been released.").

66404 F3d 812 (3d Cir 2005).

67 Id at 813-14 (noting that the parole board's sole reason for denial was "that the fair administration of justice cannot be achieved through [the petitioner's] release").
} 
AEDPA took effect. ${ }^{68}$ Accordingly, it held that a claim was not "second or successive" under the statutory definition if it couldn't have been raised in the previous petition. ${ }^{69}$ Here the new claims could have been raised at the time of the first petition, so the district court lacked jurisdiction and the petition was dismissed. ${ }^{70}$ It should be acknowledged that a good portion of the court's analysis is arguably dicta, but the case remains notable for its interpretive approach, notwithstanding the fact that the petition was denied under $\$ 2244$ (b).

The paradigmatic case of what the abuse-of-the-writ doctrine means post-AEDPA came down from the Fifth Circuit in In re Cain." After filing a habeas petition challenging his conviction and the constitutionality of his prison's "good-time credits program," Cain filed again, challenging another prison administrative policy. ${ }^{n}$ Noting that the new petition was chronologically successive to his first, the court looked to $\S 2244$ (b) and observed that the phrase "second or successive" went undefined in the act. Stepping away from the rigid textual analysis, the opinion pointed out that "a prisoner's application is not second or successive simply because it follows an earlier federal petition. Instead, § 2244-one of the gatekeeping provisions of AEDPA - was enacted primarily to preclude prisoners from repeatedly attacking the validity of their convictions and sentences." ${ }^{\text {,73 }}$ In support of this claim, the opinion mentioned that $\S 2244(\mathrm{~b})(2)(B)$ speaks of the prisoner's guilt of the underlying offense, giving the impression that challenges to postconviction administrative and disciplinary issues were not the main target of the provisions. ${ }^{74}$

This definition is then offered: "[A] later petition is successive when it: 1) raises a claim challenging the petitioner's conviction or sentence that was or could have been raised in an earlier petition; or 2) otherwise constitutes an abuse of the writ." With this definition of "second or successive," the court held that Congress did not intend $\S 2244$ to bar successive due process challenges to administrative and

68 See id at 817 ("Informed by the teachings of the Supreme Court and our sister circuits, therefore, we will look to principles of the abuse of the writ doctrine."). As this Comment shows, the circuit courts have not "uniformly" taken this interpretive approach. See Part III.B.

69 See id. Note the similarity with the definition supplied in James. See 308 F3d at 167.

70 Benchoff, 404 F3d at 820-21 ("[T]he District Court was required to have dismissed this petition.").

$71 \quad 137$ F3d 234 (5th Cir 1998).

72 Id at 235-36 ("Cain's current applications focus on the constitutionality of the procedures used to strip him of his good-time credits.").

73 Id at 235.

74 Id at 235 n 1 ("AEDPA is designed primarily to preclude petitions brought by prisoners seeking to escape the consequences of their criminal behavior.").

75 Id at 235. 
disciplinary practices of the prison, so long as the prisoner is not abusing the writ."

The Eighth Circuit faced this issue in Singleton v Norris. ${ }^{n}$ The facts are somewhat familiar-the petitioner was sentenced to death, and then filed his first federal habeas petition, including a Ford claim that wasn't reached on appeal. ${ }^{78} \mathrm{He}$ again filed for habeas relief, ${ }^{79}$ and brought the Ford claim once more. The district court dismissed the petition. On appeal the Eighth Circuit affirmed the dismissal but remarked "that a future Ford claim based on changed circumstances was not foreclosed." ${ }^{\text {"0 }}$ After this petition, he was involuntarily placed on antipsychotic medication, and he re-petitioned the district court, alleging that the state could not restore, through forced medication, his psychological fitness to be executed. ${ }^{81}$ The Eighth Circuit found that, despite the two prior habeas applications, the petition was not second or successive. Applying pre-AEDPA principles, the court held that "a habeas petition raising a claim that had not arisen at the time of a previous petition is not barred by $\S 2244$ (b) or as an abuse of the writ." ${ }^{, 82}$ Because the claim did not arise until the prisoner was put on the involuntary medical regime and had an execution date, it could not have been brought earlier. ${ }^{83}$

Both the Ninth and Eleventh Circuits have also witnessed scenarios similar to those above. The prisoner in Hill v Alaska $a^{34}$ had previously brought numerous postconviction habeas petitions, one of which challenged Alaska's mandatory parole scheme. Upon review the court examined a potential pitfall under $\S 2244(\mathrm{~b}){ }^{85}$ and found it lacked bite. Echoing the reasoning of the other circuit courts, the court defined an abuse of the writ as "when a petitioner raises a habeas claim that could have been raised in an earlier petition were it not for ex-

76 Id at 236-37 ("Cain does not need this court's permission to file his two petitions because these petitions are not successive.").

77319 F3d 1018 (8th Cir 2003) (en banc). For another Eighth Circuit decision highly similar to Cain, see generally Crouch v Norris, 251 F3d 720 (8th Cir 2001).

78319 F3d at 1020-21.

79 This was prior to the enactment of AEDPA.

80 Id at 1021.

81 Id at 1021-22 (noting that "the district court denied the petition").

82 Id at 1023 .

83 Id (stating that both factors had to be present for the petitioner's claim to be ripe). Note that this case contained a spirited dissent on this issue. See id at 1029 (Loken concurring in part and dissenting in part) ("This rule is a partial judicial repeal of $\S 2244(b)(2)$ 's limitations on new claims in second or successive petitions.").

84297 F3d 895 (9th Cir 2002).

85 The state had agreed that the prisoner's petition should not be categorized as second or successive under that section. 
cusable neglect.," ${ }^{, 66}$ This claim could not have been raised earlier; it was thus not abusive.

Medberry $v$ Crosby $^{87}$ involved a similar issue, in which a state prisoner filed repeatedly for federal habeas in order to remedy allegedly unlawful disciplinary actions against him. Although the prisoner was denied the ability to file another habeas petition, ${ }^{88}$ the court held that a petition "would not be second or successive where the claim could not have been raised in an earlier petition and [did] not otherwise constitute an abuse of the writ." ${ }^{89}$

B. The Lower Courts: Petitions Containing Subsequent and Newly

Ripened Claims Are "Second or Successive"

As demonstrated above, most of the courts of appeals have taken a permissive approach to the interpretation of $\$ 2244$ (b), departing from the plain textual meaning when faced with a newly ripened claim. Yet not every court has held this way. Despite some claims that the majority of courts have allowed these chronologically successive petitions, or that the courts have "uniformly" rejected the textual argument, ${ }^{\text {, }}$ two circuits have opted for another interpretation.

The Seventh Circuit has not adopted the Cain model. In the paradigmatic case In re Page, ${ }^{\text {,1 }}$ the petitioner, not surprisingly, had his first petition denied on the merits and brought a second petition based on a decision that had not been handed down at the earlier time. The court wrote that the petitioner "misses the essential distinction between a dismissal of a petition for habeas corpus for technical procedural reasons, of which the most common is a failure to exhaust state remedies, and a dismissal on the merits." ${ }^{\text {"27 }}$ In the first circumstance, the petitioner still has the opportunity for federal habeas review. In Page, however, the first petition was denied on the merits, and the petitioner attacked the same judgment under fire in the first petition. ${ }^{93}$ The court characterized the petitioner's argument as saying that

if there is a reason for filing a second petition - a reason why the claim could not have been included in the first petition - then the second petition is really a first petition. But this is equivalent to

Id at 898.

351 F3d 1049 (11th Cir 2003).

Id at 1064 .

Id at 1062.

See, for example, Benchoff, 404 F3d at 817.

179 F3d 1024 (7th Cir 1999).

Id at 1025 .

Id. 
arguing that a second petition should be treated as a first petition so long as it is not an "abuse of the writ."

Citing an earlier Seventh Circuit case, the court explained that the abuse-of-the-writ doctrine is "defunct" and has been entirely supplanted by the provisions of $\S 2244(\mathrm{~b}) .^{95}$ Allowing a habeas petitioner to choose between the older equitable standard and that established by AEDPA "is a slap in the face of Congress."

In addition to this argument, the court analyzed the structure of AEDPA's second or successive provisions. Noting that $\$ 2244(\mathrm{~b})(2)(A)$ allows a circuit court to entertain a claim relying on new, previously unavailable constitutional law that the Supreme Court has made applicable to collateral attacks, the Seventh Circuit panel found it contradictory that a court should entertain a successive claim based on new law if any claim based on new law would not be successive. ${ }^{97} \mathrm{Be}-$ cause this seemed to be the petitioner's argument, the court denied the petition.

The Seventh Circuit held the same way in the similar case of Lambert $v$ Davis. ${ }^{98}$ The petitioner, after having his first habeas petition denied on the merits, filed another application for federal habeas corpus based on a decision of the state supreme court that had come down after the first petition. The court found it successive under AEDPA because it "attack[ed] the same judgment based on the same argument," and because the issue was a matter of state law, and thus unavailable for federal habeas review. ${ }^{100}$ The dissent, on the other hand, focused on the "term of art" language from Slack $v$ McDaniel. ${ }^{101}$ The dissenting judge thought there to be no dispute that AEDPA was intended to put a stop to frivolous habeas petitions that merely clogged the courts. ${ }^{102}$ However,

94 Id.

95 Id at 1025, quoting Burris v Parke, 95 F3d 465, 469 (7th Cir 1996). Compare this finding with the Supreme Court's decision in Felker, 518 US at 664 (acknowledging a viable abuse-ofthe-writ doctrine after AEDPA).

96 Page, 179 F3d at 1026.

97 Id (finding that, if "a claim based on a new (hence previously unavailable) case is not a second or successive petition at all," then part of $\S 2244$ 's language would "never come into play").

98449 F3d 774 (7th Cir 2006), cert denied 127 S Ct 1814 (2007).

$99449 \mathrm{~F} 3 \mathrm{~d}$ at 777 .

100 Id at 778-79 (noting in addition that "the state supreme court reasonably rejected [petitioner's] due process and equal protection claims").

101529 US 473 (2000). See also note 57.

102 Id at 780 (Ripple dissenting) ("There is no question that, in enacting AEDPA, Congress desired to put an end to the constant stream of habeas petitions that were filed successively for no other reason than to prolong the judicial process."). 
[i]t is difficult to imagine that, when Congress enacted AEDPA in an attempt to curb the filing of serial petitions that did nothing more than revisit already-litigated matters, it intended to prevent the redress of the type of grievance we have here - an action that could not have been known or even anticipated at the time the petitioner pursued the initial federal habeas claim. ${ }^{103}$

Two things are evident here. The first is the tension between the Page majority's focus on text and structure and the Lambert dissent's attention to congressional purpose. The second is that the two approaches quite obviously lead to opposite conclusions.

The other court of appeals that allies itself with the Seventh Circuit in this area is the Tenth Circuit. In Nguyen $v$ Gibson, ${ }^{105}$ the court was presented with a chronologically second petition raising a Ford incompetency-to-be-executed claim. Grappling with the Supreme Court's decision in Martinez-Villareal, the court distinguished that case from the one at bar by noting that in Martinez-Villareal, the petitioner raised the Ford claim in his original petition. Conversely, the Nguyen petitioner did not, despite the fact that "all of the operative facts were known at the time he filed his first petition." ${ }^{106}$ The dissent, however, argued that Ford claims do not sit so harmoniously with AEDPA restrictions, insofar as "a Ford claim does not ripen until execution is imminent, [thus] a Ford claim will rarely, if ever, be resolved in a first federal habeas application filed by a prisoner., ${ }^{107}$ This case, however, is almost factually indistinguishable from the Supreme Court decision in Panetti, which complicated-but did not entirely resolvethis issue. That case will be examined next.

\section{RECENT DEVELOPMENTS: THE COURT'S PRAGMATIST FLOURISH AND ITS LIMITATIONS}

The circuits were rent over this question only for a short while. But were they really? A decision handed down by the Supreme Court in 2007 ostensibly sheds some light on this question, but might be too limited in scope to resolve the issue conclusively.

103 Id at 781.

104 It might be slightly erroneous to imply that the court in Page did not evince a certain degree of purposivism, see 179 F3d at 1026 ("Such an interpretation ... is a slap in the face of Congress."), but the contrast between the approaches is the main point.

105162 F3d 600 (10th Cir 1998).

106 Id at 601.

107 Id at 602 (Briscoe dissenting). 


\section{A. Panetti}

The procedural posture of Panetti is similar to several cases already reviewed. The petitioner was convicted of a double murder before a Texas court and sentenced to death. He attacked his conviction on direct review and through state habeas, but received no relief. After this, he filed a habeas petition in federal court under $\$ 2254$, which was denied. This denial was affirmed on appeal. ${ }^{108}$ The arguments presented in this petition did not include a Ford incompetency-to-beexecuted claim, despite the fact that the petitioner was pretty clearly not in the best of psychological health all throughout the judicial proceedings. $^{109}$ At the close of the habeas proceedings, a new execution date was set, and the petitioner refiled for habeas relief on his incompetency claim, ${ }^{110}$ arguing that the prisoner didn't understand the reason for his execution. The district and circuit courts denied relief, and the Supreme Court granted certiorari on an unusual aspect of Ford's Eighth Amendment jurisprudence. ${ }^{111}$ The Eighth Amendment claim, while ultimately determined by the Supreme Court, is not relevant for this analysis. The particular import of this case was that the $\S 2244$ (b) issue seemed to go entirely unnoticed by the trial court, circuit court, and initially the Supreme Court. ${ }^{112}$ Not long before oral arguments,

108 Panetti, 127 S Ct at 2848-49 (2007).

109 The psychiatric evaluation carried out by the trial court "indicated that petitioner suffered from a fragmented personality, delusions, and hallucinations.... Evidence later revealed that doctors had prescribed medications for petitioner's mental disorders that, in the opinion of one expert, would be difficult for a person not suffering from extreme psychosis even to tolerate." Id at 2848 . Even further, "[d]uring his trial petitioner engaged in behavior later described by his standby counsel as 'bizarre,' 'scary,' and 'trance-like."' Id at 2849 . The petitioner represented himself at trial, but during state habeas review the court ruled that he was incompetent to decline the appointment of an attorney. Id.

110 For an incompetency-to-be-executed claim to succeed, the execution must be imminent. When a prisoner is attacking his death sentence, the execution is almost always stayed and thus not imminent. By their very nature, Ford claims evade review, at least in a certain manner. See Part IV.B.

111 The question upon which certiorari was granted was: "Does the Eighth Amendment permit the execution of a death row inmate who has a factual awareness of the reason for his execution but who, because of severe mental illness, has a delusional belief as to why the state is executing him, and thus does not appreciate that his execution is intended to seek retribution for his capital crime?" See Petition for Writ of Certiorari, Panetti v Quarterman, No 06-6407, *i (filed Sept 6, 2006), available on Westlaw at 2006 WL 3880284. More specifically, "the district court found based on the testimony of the experts that Panetti is aware that he will be executed, that he committed the murders for which he was convicted and sentenced to death, and that the 'State's stated reason for executing him is that he committed two murders." Panetti v Dretke, 448 F3d 815, 817 (5th Cir 2006). He thought, however, that the state was lying. The real reason for the execution, in the petitioner's view, was that the State of Texas was "in league with the forces of evil to prevent him from preaching the Gospel." Id at 817-18.

112 There is some contention that the issue was raised in the district court. The State's supplemental brief mentions that it was argued in that court. Supplemental Brief for Respondent, Panetti v Quarterman, No 06-6407, *2 (filed Apr 11, 2007), available on Westlaw at 2007 WL 
however, the Court ordered supplemental briefing on the $\S 2244$ (b) issue. $^{113}$

The Court ruled that the second petition was not "second or successive" under $\$ 2244$ (b). The opinion speaks directly to the state's argument that, in order to preserve a Ford claim, the petitioner must bring it in the first petition, despite its lack of ripeness. ${ }^{14}$ Such a result, the court explained, was "counterintuitive" and "would add to the burden imposed on courts, applicants, and the States, with no clear advantage to any." It concluded that "there is another reasonable interpretation of $\S 2244$, one that does not produce these distortions and inefficiencies." ${ }^{116}$

That interpretation derived from the one employed in MartinezVillareal, one which looks beyond the statutory text to realize the "true" intent of Congress. In Martinez-Villareal, the court took account of the decision's potential "implications for habeas practice," 17 and the Panetti court took the same route, allowing the interpretation of $\S 2244$ to be shaped by decidedly pragmatic considerations of efficiency, burdens, and smooth petitioning. ${ }^{118}$ The precedent of MartinezVillareal bore particular relevance, as the decision went so far as to hold that the term "second or successive" "takes its full meaning from our case law." 119 In addition, the Court found the abuse-of-the-writ doctrine to be at least still worth mentioning, and it noted that the petitioner had in no way abused the writ by bringing the Ford claim when it became ripe, and not before. ${ }^{120}$

\section{B. The Limits of Panetti and Martinez-Villareal}

The Panetti decision is unambiguously relevant to the dispute over the interpretation of $\S 2244$ (b). The decisions of the circuit courts that define this dispute, however, do not all deal with Ford claims,

\footnotetext{
1090395 ("Supplemental Brief for Respondent"). The district court opinion contains no such mention. See generally Panetti v Dretke, 401 F Supp 2d 702 (WD Tex 2004). The district court evidently disposed of it in a motion, and the state chose not to raise the issue before the court of appeals, which, according to the state's brief, declined to hear any AEDPA issues anyway. See Supplemental Brief for Respondent at *2-3.

113 See Panetti v Quarterman, No 06-6407 (Apr 2, 2007) (docket entry ordering supplemental briefing).

114 See Panetti, $127 \mathrm{~S} \mathrm{Ct}$ at 2852.

115 Id at 2852-53.

116 Id at 2853.

117 Martinez-Villareal, 523 US at 644.

118 See Panetti, $127 \mathrm{~S} \mathrm{Ct}$ at 2854-55 ("We are hesitant to construe a statute, implemented to further the principles of comity, finality, and federalism, in a manner that would require unripe (and, often, factually unsupported) claims to be raised as a mere formality, to the benefit of no party.").

119 Id at 2853 (emphasis added).

120 Id at 2854-55.
} 
whereas Martinez-Villareal and Panetti do. Are these cases limited to this one species of claim?

Martinez-Villareal does not appear to be. As stated previously, the petitioner's Ford claim was dismissed for failure to exhaust state remedies $^{121}-$ a procedural shuffle that in no way related to the nature of the claim itself. The Court said this in so many words:

$[\mathrm{N}]$ one of our cases expounding [the exhaustion] doctrine have ever suggested that a prisoner whose habeas petition was dismissed for failure to exhaust state remedies, and who then did exhaust those remedies and returned to federal court, was by such action filing a successive petition. A court where such a petition was filed could adjudicate these claims under the same standard as would govern those made in any other first petition. ${ }^{122}$

The rule of Martinez-Villareal would apply with equal force and manner to, say, an ineffective-assistance-of-counsel claim, a Batson challenge, ${ }^{123}$ or any other claim that can be brought on habeas.

The same cannot be said about Panetti, which is explicitly limited to claims of incompetency to be executed. The case never would have arisen without the peculiar nature of Ford claims. As stated previously, in order for a Ford claim to ripen, execution must be imminent. ${ }^{124}$ As a result, these claims can be unripe in two different ways: they can be factually unripe insofar as the prisoner is not insane, or they can be legally unripe insofar as the prisoner is insane, but the execution is not imminent. The rule of Martinez-Villareal explicitly collapses this distinction $;^{125}$ the rule of Panetti could not exist without it.

Scott Panetti was obviously insane well before he filed his first federal habeas petition. ${ }^{126}$ At the time of this first petition, therefore, the claim was as factually ripe as it would ever be. Were that the end

121 Martinez-Villareal, 523 US at 644. See also Part II.B.

122 Id at 644.

123 See Batson v Kentucky, 476 US 79, 89 (1986) ("[T]he Equal Protection Clause forbids the prosecutor to challenge potential jurors solely on account of their race or on the assumption that black jurors as a group will be unable impartially to consider the State's case against a black defendant.").

124 Martinez-Villareal, 523 US at 644-45.

125 See id:

We believe that respondent's Ford claim here-previously dismissed as premature-should be treated in the same manner as the claim of a petitioner who returns to federal court after exhausting state remedies. True, the cases are not identical; respondent's Ford claim was dismissed as premature, not because he had not exhausted state remedies, but because his execution was not imminent and therefore his competency to be executed could not be determined at that time. But in both situations, the habeas petitioner does not receive an adjudication of his claim.

126 See note 111 and accompanying text. 
of the inquiry, this second petition would never pass the threshold of $\S 2244$ (b). But it wasn't - the Court's decision accounted only for the unusual delayed ripeness brought about by Ford claims.

The language of the opinion makes this clear. In divining congressional intent, the court concluded "that Congress did not intend the provisions of AEDPA addressing 'second or successive' petitions to govern a filing in the unusual posture presented here: a $\$ 2254$ application raising a Ford-based incompetency claim filed as soon as that claim is ripe." ${ }^{127}$ This is just an exception for Ford claims; for every other kind of claim, $\$ 2244$ (b) retains its bite. "In the usual case, a petition filed second in time and not otherwise permitted by the terms of $\S 2244$ will not survive AEDPA's 'second or successive' bar." ${ }^{128}$ Panetti has no application outside of Ford claims.

\section{THE UNTENABLE STATUS QUO}

Any solution to the interpretive conflict over § 2244(b) will benefit from an evaluation of the arguments that have already been marshaled by the courts. None of the approaches seems fully to take account of the structural and constitutional topographies of the AEDPA provisions, and none grapples with the other arguments in a meaningful way. Before proposing a solution, the analytical methods must be examined. Furthermore, if possible alternatives to AEDPA are available for prisoners to seek review of their claims, the problem presented in this Comment might be a mere chimera. This Part will also explore substitutes for habeas relief that do not necessarily implicate AEDPA.

\section{A. The Methods of Analysis in the Case Law Are Flawed}

The two sets of circuits presented above take dramatically dissimilar approaches to this problem, but neither is satisfying. The $\mathrm{Pa}$ netti method also leaves much to be desired. One elementary problem is this: to what extent did AEDPA uproot the common law abuse-ofthe-writ principle, and to what extent must the circuit courts favor the purpose of AEDPA over its text after Martinez-Villareal? One set of courts prefers the textual analysis, the other leans toward purposivism. Panetti puts a pragmatist spin on the liberal (purposivist) approach. Much depends on the correct answer, but neither is obviously correct.

127 Panetti, $127 \mathrm{~S} \mathrm{Ct}$ at 2853 (emphasis added).

128 Id at 2855 . 
The Supreme Court has given a nod to the continued vitality of abuse-of-the-writ jurisprudence, ${ }^{129}$ but its current borders are unclear. Canons of construction are of little help. One such canon dictates that "statutes in derogation of the common law" are to be approached narrowly. ${ }^{130}$ A countercanon is "that 'remedial' statutes are to be broadly construed." ${ }^{131}$ It does not take a literary critic to point out that these canons can be deployed to achieve opposing results. ${ }^{132}$ Section 2244(b) certainly goes against the grain of the common law, but whether it is a remedy or is "in derogation" thereof is predominately a matter of legislative intent and conflicting values. Because this question seems to lead inexorably to indeterminacy, it should probably be avoided. A cleaner textual reading is available.

The Supreme Court held, quite some time ago, that "[n]o statute is to be construed as altering the common law, farther than its words import." ${ }^{133}$ The Felker and Martinez-Villareal courts ruled narrowly in order to make the rulings fit with the statutory framework. The latter case, in holding that "second or successive" did not apply to a petition containing a claim that had been previously dismissed on procedural grounds, tightly worked the common law principle into AEDPA's text. Whether the words of $\S 2244$ (b) can be imported farther than that case, however, is open to doubt. Panetti appears to depart considerably from the text of $\$ 2244$ (b), but for the limited purpose of Ford claims. This is the dispute that the lower courts have wrangled over.

The first set of circuit courts, which incorporate the pre-AEDPA abuse-of-the-writ principles in their analysis, seem to neglect the persuasive structural argument from Page. It cannot be denied that the full usage of the abuse-of-the-writ doctrine elides the argument that, if arguments that rely on new, previously unavailable law are not second or successive under the statutory framework, then $\S 2244$ (b)(2)(A) serves little purpose. If claims that rely on the discovery or development of new facts-but facts that do not point toward innocence of the underlying offense - are not second or successive, then $\S 2244$ (b)(2)(B) is extraneous. As a matter of statutory interpretation, these are untenable conclusions. Another canon - the rule against surplusage-holds

129 See, for example, id at 2854-55; Felker, 518 US at 664. See also Part II.A. But see Page, $179 \mathrm{~F} 3 \mathrm{~d}$ at 1025 (observing that, after AEDPA's enactment, the abuse-of-the-writ doctrine "was replaced by the new criteria and passed out of the law").

130 William N. Eskridge, Jr., Philip P. Frickey, and Elizabeth Garrett, Legislation and Statutory Interpretation 343-44 (Foundation 2d ed 2006).

131 Id.

132 This general observation is not novel. See generally Karl N. Llewellyn, Remarks on the Theory of Appellate Decision and the Rules or Canons about How Statutes Are to Be Construed, 3 Vand L Rev 395 (1950).

133 Shaw v Railroad Co, 101 US (11 Otto) 557, 565 (1879). 
that statutes are to be interpreted such that each provision has independent meaning. ${ }^{134}$ Statutory clauses are presumed not to be purely aesthetic or redundant. They do not contain filler.

The Cain decision, which came down in the uncertain aftermath of Martinez-Villareal, violates this canon, as well as elementary principles of textualism. It held that petitions are "successive" in only two circumstances: when they "constitute[] an abuse of the writ," or when they "raise[] a claim challenging the petitioner's conviction or sentence that was or could have been raised in an earlier petition." ${ }^{135}$ In holding that a petition is "successive" when it abuses the writ, that decision ignores the words of $\S 2244$ altogether. But when it holds that any challenge that couldn't have been brought earlier is not successive, $\S 2244$ (b)(2) has little work to do. The subsections of that clause make it abundantly clear that claims that are brought under such circumstances are second or successive and will be granted only in particular circumstances. ${ }^{136}$ Put simply, Cain posits that a broad set of petitions are not second or successive. But the plain text of $\S 2244$ (b) indicates that a narrow subset of those petitions are second or successive, and cannot automatically be accepted by the district court. It is difficult to square the Cain interpretation with the statutory language, and it is unclear what lessons can be drawn from Martinez-Villareal.

The Panetti decision makes all the mistakes of Cain and the liberal approach, but throws a few more dubious interpretive methods into the mix. While that decision doesn't rely as heavily on the abuseof-the-writ doctrine as some of the cases that take the liberal tack, it manufactures an exception to the plain text of $\S 2244(b)$ - an exception that has little support in the statute. Declaring that the phrase "second or successive" "takes its full meaning from [the] case law,",37 the Supreme Court unshackled itself from any intrinsic meaning that the words or structure of the statute provide. Secondly, by mooring the interpretation of $\S 2244$ to naked considerations of practicality - to say nothing of the fact that the point of reference in Martinez-Villareal was pretty clearly dicta - the Court transformed itself into an oversight board for efficient petitioning. Lastly, its divination of congressional intent strangely fails to pay much attention to the statute, or to

134 See Eskridge, Frickey, and Garrett, Legislation at 275-76 (cited in note 130).

135 Cain, 137 F3d at 235.

136 Specifically, if claims "rel[y] on a new rule of constitutional law, made retroactive to cases on collateral review by the Supreme Court, that was previously unavailable," or the facts couldn't have been uncovered through "due diligence" and the claims establish the petitioner's innocence to a high standard, then those claims shall not be dismissed. 28 USC $\$ 2244$ (b)(2).

137 Panetti, $127 \mathrm{~S} \mathrm{Ct}$ at 2853. 
Congress at all. Suffice it to say that Panetti is not an interpretive panacea for AEDPA's troubles.

While these two approaches seem inappropriately casual with respect to interpretation, the more rigid textual and structural approach of Page has the potential to foreclose any possibility of judicial relief on claims that cannot or do not become ripe until after a prisoner's first federal habeas petition. This seems a similarly unacceptable state of affairs. In fact, because the Constitution stands supreme to any legislative act, ${ }^{138}$ such a scenario is undesirable in the extreme. While courts have an obligation to be faithful to the text of a congressional act, they have an anterior obligation of fidelity to the Constitution of the United States. This does not mean, however, that interpretations of statutes are less valid as a logical matter, and the Page analysis bears a great deal of explanatory appeal. But, even if that is the superior interpretation, what of the possible denial of valid constitutional rights?

What potential rights might be violated by this approach? Consider the following scenarios. A prisoner is convicted in state court and files her one habeas petition of right. She has taken her bite at the apple, and $\S 2244$ (b) implies that that's all she gets. But the circumstances of her sentence could violate her constitutional rights. The disciplinary procedures at the prison could be misused to violate her due process rights, ${ }^{139}$ a parole miscalculation could similarly deprive the prisoner of due process, ${ }^{140}$ or even could go so far as to violate the Eighth Amendment. Violations of prisoners' First Amendment rights to freedom of religion are far from uncommon. ${ }^{141}$ Just as children do not abandon their constitutional rights as they pass through the schoolhouse gates, prisoners retain some constitutional rights after the doors have clanked shut behind them.

Valid constitutional challenges to the sentence itself can also arise after the adjudication of the first habeas petition. For prisoners on death row, the method of execution may present Eighth Amendment

138 US Const Art VI, cl 2 ("This Constitution ... shall be the supreme Law of the Land; and the Judges in every State shall be bound thereby, any Thing in the Constitution or Laws of any State to the Contrary notwithstanding."); Marbury v Madison, 5 US (1 Cranch) 137, 138 (1803) ("An act of congress repugnant to the constitution cannot become a law.").

139 See, for example, Medberry, 351 F3d at 1052-54 (finding one such petition moot).

140 See, for example, James, 308 F3d at 165 (describing a petition that "alleged that [the prison system] had failed to apply the credit for time served on [petitioner's] lesser sentence to his overall sentence").

141 There is, however, an alternative route to vindicate these rights other than habeas corpus-specifically the Religious Land Use and Institutionalized Persons Act. For a discussion of this issue, see generally Jennifer D. Larson, RLUIPA, Distress, and Damages, 74 U Chi L Rev 1443 (2007) (resolving a tension between the Religious Land Use and Institutionalized Persons Act of 2000 and the Prison Litigation Reiv:.. Act of 1995). 
concerns. ${ }^{1.2}$ In fact - though the possibility is exceedingly remote at the present time-were the penalty of death to be declared unconstitutional tout court, constitutional claims could be brought by prisoners awaiting execution. ${ }^{143}$ But less fantastical circumstances can be envisioned. A prisoner could be convicted in an appallingly corrupt trial, though the particular facts may not be uncovered until after the initial habeas petition is duly adjudicated. ${ }^{144}$ Further, a prisoner who does not manifest signs of defects in intelligence and ability until after the denial of the first petition could have a potential claim. ${ }^{145}$ Constitutional

142 See Hill v McDonough, 126 S Ct 2096, 2100 (2006) (evaluating an Eighth Amendment challenge against the particular combination of chemicals in a lethal injection cocktail, which could potentially leave the prisoner conscious but paralyzed during muscle seizure and cardiac arrest). See also Leonidas G. Koniaris, et al, Inadequate Anaesthesia in Lethal Injection for Execution, 365 Lancet 1412, 1414 (2005) ("Failures in protocol design, implementation, monitoring and review [of lethal injections] might have led to the unnecessary suffering of at least some of those executed."). Challenges to the "validity of any confinement or to particulars affecting its duration" must be vindicated through habeas corpus; challenges to the circumstances of confinement may be brought under 42 USC $\S 1983$. Muhammad v Close, 540 US 749, 750 (2004). Furthermore, challenges to execution methods could amount to a challenge to "the fact of the sentence itself," which must be brought in a habeas action. Nelson v Campbell, 541 US 637, 644 (2004). In Hill, the petitioner was allowed to challenge the circumstances of his execution under $\S 1983$ because he did not challenge "an execution procedure required by law" and a legal victory "would not necessarily prevent the State from executing him by lethal injection." $126 \mathrm{~S} \mathrm{Ct}$ at 2102 . It is far from difficult, however, to imagine a scenario wherein a challenge was brought to a method required by law, or that a successful suit would foreclose the availability of execution altogether. For a fuller explanation of this debate, as well as a proposed test for evaluating claims, see generally Note, $A$ New Test for Evaluating Eighth Amendment Challenges to Lethal Injections, 120 Harv L Rev 1301 (2007).

143 Of course, even in such an unlikely circumstance, it is even more unlikely that the Supreme Court would neglect to make the ruling retroactive to cases on collateral review. "New" rules become retroactive to cases on collateral review in only two circumstances. The first exception is when forms of private conduct are placed beyond the reach of the criminal law, and the second is for certain procedures fundamental to the American concept of liberty. Teague v Lane, 489 US 288, 307 (1989). A ruling that the death penalty violates the Constitution would almost certainly fall into the second category. As one litigant put it, the state should not be allowed "one last cruel and unusual punishment" before the new rule takes effect. Jones $v$ Thigpen, 741 F2d 805, 811 (5th Cir 1984). The point here is merely illustrative.

144 This scenario is illustrated in Deborah L. Stahlkopf, A Dark Day for Habeas Corpus: Successive Petitions under the Anti-Terrorism and Effective Death Penalty Act of 1996, 40 Ariz L Rev 1115, 1134-35 (1998) ("To draw an arbitrary line based on timing, over which the petitioner has absolutely no control, is to deny the petitioner his constitutional rights."). The author bases her hypothetical on Bracey $v$ Gramley, 520 US 899, 908-09 (1997) (ruling that an inmate sentenced by a judge later convicted of unrelated bribery had shown good faith for discovery). Again, innumerable variations on this theme are possible.

145 See Atkins v Virginia, 536 US 304, 321 (2002) (holding the execution of the "mentally retarded" to be unconstitutional under the Eighth Amendment). It is notable that this case overturned a directly contrary ruling handed down just thirteen years prior. See Penry $v$ Lynaugh, 492 US 302, 335 (1989) ("[A]t present, there is insufficient evidence of a national consensus against executing mentally retarded people convicted of capital offenses for us to conclude that it is categorically prohibited by the Eighth Amendment."). 
age or category restrictions on execution after Roper $v$ Simmons ${ }^{146}-$ if not made retroactive to cases on collateral review-could pose thorny questions if the decision is handed down while an applicable prisoner is awaiting death.

Can these be vindicated under the more rigorous textual and structural analysis of $\S 2244$ (b)? This question must be set aside momentarily. Before any sweeping pronouncements of constitutional infidelity are made, it must be investigated whether habeas petitioners have alternative remedies available to them. If so, the textual interpretation should control.

\section{B. Alternatives to AEDPA}

Despite the fact that AEDPA unambiguously controls the filing of habeas petitions - especially those that might be considered second or successive - in a United States district court, there are other avenues through which prisoners can try to vindicate their rights. Two potential remedies that require mentioning are original habeas petitions in the Supreme Court and the constitutional tort remedy of 42 USC $\$ 1983 .^{147}$ In addition, prisoners may be able to argue for a remedy on the basis of the Suspension Clause of the U.S. Constitution.

146543 US 551, 568 (2005) (holding unconstitutional under the Eighth Amendment the execution of inmates who were either seventeen or eighteen years old when they committed their crimes).

14742 USC $\$ 1983(2000)$. It has been suggested that other writs, such as coram nobis or audita querela, be resuscitated and mobilized under 28 USC $\$ 1651$ (2000), the "All-Writs Act." See Peter Hack, The Roads Less Traveled: Post Conviction Relief Alternatives and the Antiterrorism and Effective Death Penalty Act of 1996, 30 Am J Crim L 171, 211-21 (2003) (defining coram nobis as a writ that "allowed courts to review decisions that had previously been laid to rest" and audita querela as affording "relief to a judgment debtor against a judgment or execution because of some defense of discharge arising subsequent to the rendition of the judgment"). Despite the fact that these writs have been abolished in the civil context, see FRCP 60 (b), coram nobis was briefly revitalized in United States $v$ Morgan, 346 US 502, 512 (1954) (allowing the writ of coram nobis to issue for "errors 'of the most fundamental character"). More recent courts, however, have been less receptive to this strategy. As Judge Easterbrook remarked,

Prisoners cannot avoid the AEDPA's rules by inventive captioning.... Call it a motion for new trial, arrest of judgment, mandamus, prohibition, coram nobis, coram vobis, audita querela, certiorari, capias, habeas corpus, ejectment, quare impedit, bill of review, writ of error, or an application for a Get-Out-of-Jail Card; the name makes no difference. It is substance that controls.

Melton v United States, 359 F3d 855, 857 (7th Cir 2004). These writs will not be addressed here. 


\section{Original petitions for writs of habeas corpus in the United States Supreme Court.}

As stated previously, $\S 2254$ states that

[t]he Supreme Court, a Justice thereof, a circuit judge, or a district court shall entertain an application for a writ of habeas corpus in behalf of a person in custody pursuant to the judgment of a State court only on the ground that he is in custody in violation of the Constitution or laws or treaties of the United States. ${ }^{148}$

Because prisoners in state courts, after exhausting their state remedies, overwhelmingly petition for habeas in the appropriate federal district court, it can be easily forgotten that they still have the opportunity to file for an original petition in the Supreme Court.

This point received some attention in Felker. ${ }^{199}$ There the Court analyzed whether $\S 2244(b)(3)(E)$, which prevented the justices from reviewing the decisions of the three-judge panel, eviscerated the Court's ability to entertain original petitions for habeas in violation of Article III, $\$ 2$ of the Constitution. ${ }^{150}$ Finding no violation, the decision concluded that the jurisdiction to receive original habeas petitions remained essentially untrammeled.

As an interpretive matter, the Felker court did not conclusively decide whether its approach to original petitions was bound by the

14828 USC $\$ 2254$ (emphasis added).

149518 US at 661-62 ("[AEDPA] does not repeal [the Court's] authority to entertain a petition for habeas corpus."). See also Part II.A.

150 Id. See also note 31 and accompanying text.

151 Id. See also US Const Art III, \& 2 ("In all the other Cases before mentioned, the Supreme Court shall have appellate Jurisdiction ... with such Exceptions, and under such Regulations as the Congress shall make") (emphasis added); Yerger, 75 US at 98 (listing habeas and mandamus as included in the Court's appellate jurisdiction). Felker held that the Supreme Court is not divested of appellate jurisdiction under Article III because its ability to entertain original writs hadn't been altered by AEDPA. See 518 US at $661-62$. This is an interesting logical pirouette, because habeas writs are generally considered to be original civil actions. See, for example, Townsend v Sain, 372 US 293, 311-12 (1963) ("The whole history of the writ refutes a construction of the federal courts' habeas corpus powers that would assimilate their task to that of courts of appellate review."). The Court, however, couldn't have considered an original writ of habeas corpus as part of its original jurisdiction without a collision with Marbury, as original writs are not mentioned in Article III. The characterization may be somewhat defensible, however. An original habeas writ in the Supreme Court is a review of some decision, and certain nonappellate aspects of habeas review that crop up in federal district courts-such as determinations of fact and the ability to hold evidentiary hearings - are simply not present in the Supreme Court. There is at least an argument that a state is a de facto litigant in habeas proceedings because a state prisoner is challenging her sentence in federal court, and this would allow the proceedings to qualify under the Court's original jurisdiction. The proper litigant in a habeas suit, however, is not the state, but rather the direct custodian over the prisoner's confinement. See, for example, al-Marri v Rumsfeld, 360 F3d 707, 708-09 (7th Cir 2004). 
strictures of $\S 2244$ (b). It pointed out that the gatekeeping provisions of $\S 2244$ (b)(3) do not apply to original petitions, insofar as the statutory text is abundantly clear. ${ }^{152}$ Sections 2244 (a) and (b), on the other hand, contain no such demonstrable limitations. The court took note, however, that "[w]hether or not we are bound by these restrictions, they certainly inform our consideration of original habeas petitions." ${ }^{153}$

All this notwithstanding, the notion that original petitions for habeas in the Supreme Court may provide an alternate remedy to $\S 2244$ (b) is substantially open to doubt. First of all, the Court intimated that it would consider the restrictions imposed by that section. If so, an original petition can in no way be classified as an alternative to a petition brought under AEDPA. Any potential problems with AEDPA would then be mirrored in the Supreme Court's jurisprudence.

But there is a more significant reason that original petitions may not be a real substitute for filing in the lower courts: grants of such petitions are, to say the least, exceedingly rare. The last such petition to be granted by the Court was offered up more than eighty years ago, ${ }^{154}$ and there is nothing that indicates the court might begin granting them again.

In fact, all institutional signs point to no. The Supreme Court Rules themselves categorize original habeas petitions as "extraordinary writ[s]," the issuance of which is emphatically "not a matter of

152 Felker, 518 US at 662 (stating that $\S 2244($ b)(3) applies only to "applications 'filed in the district court"').

153 Id.

154 See Ex Parte Grossman, 267 US 87, 107 (1925) (granting habeas to a petitioner who was imprisoned for violation of Prohibition, notwithstanding a presidential pardon). See also Bryan A. Stevenson, The Politics of Fear and Death: Successive Problems in Capital Federal Habeas Corpus Cases, 77 NYU L Rev 699, 757, 782 (2002) (noting that the Court acknowledges the possibility of original habeas petitions but almost never grants such petitions). It is notable, however, that a 2002 petition for an original writ in the Supreme Court gathered four votes to grant. In In re Stanford, 537 US 968 (2002), the court denied a petition by a death-row prisoner who was under the age of eighteen when he committed his offense. Three Justices signed on to an exceptionally spirited dissent written by Justice Stevens. After noting that many laws (voting and jury service, for example) acknowledge that juveniles bear a lessened degree of responsibility, Stevens argued that a national consensus had developed against the execution of juvenile offenders. He concluded that "offenses committed by juveniles under the age of 18 do not merit the death penalty. The practice of executing such offenders is a relic of the past and is inconsistent with evolving standards of decency in a civilized society. We should put an end to this shameful practice." Id at 972 . This view prevailed less than three years later in Roper, 543 US at 578 ("The Eighth and Fourteenth Amendments forbid imposition of the death penalty on offenders who were under the age of 18 when their crimes were committed."), which overturned the previous precedent of Stanford $v$ Kentucky, 492 US 361, 380 (1989) ("[W]e conclude that [the execution of offenders younger than 18 at the time of their crimes] does not offend the Eighth Amendment's prohibition against cruel and unusual punishment."). The petitioner in that case was the same whose original habeas petition in the Supreme Court was denied in In re Stanford. 
right, but of discretion sparingly exercised." ${ }^{155}$ Extraordinary is the right word for it. The Rules inform potential litigants that, before the Court will consider issuing an original writ, "the petition must show that the writ will be in aid of the Court's appellate jurisdiction, that exceptional circumstances warrant the exercise of the Court's discretionary powers, and that adequate relief cannot be obtained in any other form or from any other court." ${ }^{\text {"s6 }}$ Specifically for original petitions, the Rules tersely counsel litigants that "[ $[\mathrm{t}]$ his writ is rarely granted."

As categorical as this language sounds, commentators go further. A leading treatise on Supreme Court practice notes that

this power to issue an "original" writ of habeas corpus directly from the Court or a Justice is so circumscribed, so rarely exercised, and so often misunderstood by untutored petitioners as to be deemed "an anachronism" in Supreme Court practice. Many habeas corpus petitions have been filed directly with the Court in past years, and an appreciable number continue to be filed. Almost without exception, these petitions have been summarily denied. It is somewhat an understatement to say ... that " $[t]$ his writ is rarely granted." 1 158

It is abundantly clear that an original petition for a writ of habeas corpus in the Supreme Court cannot be counted upon as a remedy. Suffice it to say that it is not a viable alternative to the habeas provisions of AEDPA.

\section{Section 1983 suits.}

It is possible that, as an alternative to AEDPA habeas provisions, a petitioner with legitimate claims might be able to seek vindication under the constitutional tort doctrine of $\S 1983$. That commonly used section allows those whose rights are violated at the hands of government officials to bring suit against the perpetrators. ${ }^{159}$ This is perhaps best described as a partial remedy.

The description as partial derives from the fact that the scope of the remedy in the context of $\S 1983$-as-habeas-substitute has been limited by the Supreme Court. In Wilkinson $v$ Dotson, ${ }^{160}$ the Court

155 Sup Ct R 20.1.

156 Id.

157 Sup Ct R 20.4(a).

158 Robert L. Stern, et al, Supreme Court Practice $\$ 11.3$ at 591 (Bureau of National Affairs 8th ed 2002).

159 Id (recognizing a claim by a person whose "rights, privileges, or immunities" are abrogated by another person acting under color of law).

160544 US 74 (2005). 
held that an action to alter prison parole proceedings that will not necessarily result in speedier release does not lie at the "core" of the habeas writ and is thus allowable through $\S 1983 .{ }^{161}$ Section 1983, however, is not an appropriate remedy "if success in that action would necessarily demonstrate the invalidity of confinement or its duration."

If the petitioner seeks to attack the imposition or length of her sentence directly, her $\S 1983$ action can be transformed into a habeas petition and thus is not an alternative at all. As Judge Posner wrote before the Wilkinson decision, "If, regardless of the relief sought, the plaintiff is challenging the legality of his conviction, so that if he won his case the state would be obliged to release him even if he hadn't sought that relief, the suit is classified as an application for habeas corpus." ${ }^{163}$ Depending on the effect of the prisoner's $\S 1983$ action, the court could treat it as a habeas petition, and thus subject it to the pitfalls of any ordinary habeas petition under AEDPA.

To the extent that this doesn't allow inmates to challenge the "invalidity of [their] confinement or its duration," it is generally limited in its role as a habeas substitute. For a discrete class of prisoners, it may be a full remedy. For another discrete class, however-which would include petitioners bringing claims with the potential to prevent execution altogether-it is no remedy at all. In either case, it fails to fully resolve the interpretive dispute in the lower courts over $\$ 2244(\mathrm{~b}){ }^{164}$

\section{The Suspension Clause.}

There is at least a possibility that foreclosing any potential judicial remedy for a valid constitutional claim might implicate the Suspension Clause of the United States Constitution. Because there are

161 See id at 82 (finding that the respondents' claims " $d[i d]$ not fall within the implicit habeas exception").

162 Id.

163 Heck v Humphrey, 997 F2d 355, 357 (7th Cir 1993). This ruling was affirmed in Heck v Humphrey, 512 US 477, 486-87 (1994). Furthermore, the Supreme Court held that, in order to recover damages under $\S 1983$ for unconstitutional conviction or imprisonment, a prisoner "must prove that the conviction or sentence has been reversed on direct appeal, expunged by executive order, declared invalid by a state tribunal authorized to make such determination, or called into question by a federal court's issuance of a writ of habeas corpus." Id.

164 One additional avenue of relief that has been suggested is a motion for relief from judgment under FRCP 60(b)(2) or FRCP 60(b)(6). See Stevenson, The Politics of Fear and Death, 77 NYU L Rev at 789-93 (cited in note 154) ("[T]he Supreme Court has interpreted [Rule 60(b)] expansively in accordance with the underlying purpose of bringing about just results."). Under circumstances such as those described in Stevenson's article, this might be a valid remedy to the potential constitutional problems posed by $\$ 2244(\mathrm{~b})$. Since Stevenson's article went to print, however, the Supreme Court has held that Rule 60(b) can't be used to "present new claims for relief from a state court's judgment of conviction" in an attempt to skirt AEDPA. As such, it is not a habeas substitute. Gonzalez v Crosby, 545 US 524, 531 (2005) (describing Rule 60(b) motions as "in substance a successive habeas petition"). 
few wholesale suspensions of habeas corpus, ${ }^{165}$ the adjudicatory standard for potential Suspension Clause violations is uncertain. The Second Circuit has held that the AEDPA habeas provisions "may violate the Suspension Clause if they create an 'unreasonable burden' to habeas relief." ${ }^{166}$ Suffice it to say that it's not at all clear what this means.

Even with this standard floating about, courts have not seriously considered Suspension Clause challenges to AEDPA. Felker, the first Supreme Court case to interpret AEDPA, ${ }^{167}$ sketched a model of habeas corpus as a writ subject to continual redefinition by Congress. "The added restrictions which the Act places on second habeas petitions are well within the compass of this evolutionary process, and we hold that they do not amount to a 'suspension' of the writ contrary to Article I, § 9." ${ }^{168}$

The Supreme Court has been slightly more receptive in other contexts. In INS v St. Cyr ${ }^{169}$ the Court held that when AEDPA, combined with the Illegal Immigration Reform and Immigrant Responsibility Act, entirely forecloses an immigrant's right to contest his deportation through a petition for habeas, the Suspension Clause is invoked. ${ }^{170}$ "A construction of the amendments at issue that would entirely preclude review of a pure question of law by any court would give rise to substantial constitutional questions." ${ }^{\text {171 }}$ In order to circumvent this potential collision with the Suspension Clause, the decision states that the canon of constitutional avoidance should be invoked to make a remedy available. ${ }^{172}$ Notably, the dissent argued that the Suspension Clause does not guarantee any particular content to habeas

165 Abraham Lincoln's suspension of habeas corpus during the Civil War is of course the best-known example. See Ex parte Merryman, $17 \mathrm{~F}$ Cases 144, 148 (Cir Ct Md 1861) (holding that Congress, and not the president, wields the power to suspend habeas corpus under the Suspension Clause); Ex parte Milligan, 71 US (4 Wall) 2, 115 (1866) (noting, in dicta, that "suspension of the writ does not authorize the arrest of any one, but simply denies to one arrested the privilege of this writ in order to obtain his liberty"); David P. Currie, The Civil War Congress, 73 U Chi L Rev 1131, $1134-40$ (2006) (detailing the presidential and congressional arguments for and against Lincoln's suspension of the writ).

166 James, 308 F3d at 168 (emphasis added). See also Rodriguez $v$ Artuz, 990 F Supp 275, 282 (SDNY 1998) (Sotomayor) ("[A]t least where no claim of actual or legal innocence has been raised, as long as the procedural limits on habeas leave petitioners with some reasonable opportunity to have their claims heard on the merits, the limits do not ... constitute [an unconstitutional] suspension."), affd 161 F3d 763, 764 (2d Cir 1998) (per curiam).

167 See Part II.A.

168 Felker, 518 US at 664.

169533 US 289 (2001).

170 See id at 300 .

171 Id (noting that the statutes must be construed "to avoid [constitutional] problems").

172 Id at 326 (constructing a statute not to apply retroactively in order to preserve the respondent's avenue of relief). 
corpus; rather, the clause merely prevents its wholesale suspension. ${ }^{173}$ Further, the canon of constitutional avoidance cannot be invoked to ignore the statute and, in effect, create a new one. ${ }^{174}$

Three days after the decision in St. Cyr was handed down, the court decided Zadvydas v Davis. ${ }^{175}$ In that case, the Court again supplied an extratextual remedy to sidestep constitutional difficulty. In interpreting an alien removal statute that ostensibly shut the door on habeas relief and allowed the indefinite detention of an alien, the Court found an implicit "reasonable time" limitation in the statute. As a result, the statute was saved from a potential Due Process violation. ${ }^{17}$ But, once again, the dissent didn't think so. The counterargument to the avoidance canon was marshaled in full force, alleging that the canon applies only to two equally plausible interpretations of a statute, and that the winning interpretation can't flout congressional intent. ${ }^{178}$ According to this argument, "[t]he requirement the majority reads into the law simply bears no relation to the text; and in fact it defeats the statutory purpose and design."

But these cases considered AEDPA in conjunction with other statutes, which heightened the level of constitutional questionability. The lower courts have not been more receptive to the Suspension Clause argument against AEDPA itself than the Supreme Court was in Felker. For instance, in Lindh v Murphy, ${ }^{\mathrm{g} 80}$ Judge Easterbrook surveyed a similar history of the writ, with a similar history of expansion. He remarked that "[a]ny suggestion that the Suspension Clause forbids every contraction of the powers bestowed by Congress in 1885, and expanded by the 1948 and 1966 amendments to $\S 2254$, is untenable. The Suspension Clause is not a ratchet." ${ }^{181}$ Other circuits have been similarly unreceptive. ${ }^{182}$

173 Id at 337 (Scalia dissenting) (reading the Constitution's text as providing neither content for habeas nor "even [its] existence"). But see Gerald L. Neuman, The Habeas Corpus Suspension Clause after INS v. St. Cyr, 33 Colum Hum Rts L Rev 555, 559, 571 (2002) (characterizing the St. Cyr dissent as "unprecedented" and accusing it of "ignor[ing] voluminous contrary evidence").

174 St. Cyr, 533 US at 335-36 (Scalia dissenting) (accusing the majority of "transmogrifying a doctrine designed to maintain 'a just respect for the legislature,' into a means of thwarting the clearly expressed intent of the legislature") (citations omitted).

175533 US 678 (2001).

176 See id at 682 (reasoning that the "indefinite detention of aliens [already admitted to the United States] would raise serious constitutional concerns").

177 See id at 690 (noting that civil, noncriminal detention violates Fifth Amendment due process except in extraordinary circumstances).

178 See id at 707 (Kennedy dissenting) (accusing the majority of "waltz[ing] away from any analysis of the language, structure, or purpose of the statute").

179 Id.

18096 F3d 856 (7th Cir 1996) (en banc), revd on other grounds, 521 US 320 (1997).

18196 F3d at 868. Scalia makes this same argument in his St. Cyr dissent, though it wasn't accepted by the majority. St. Cyr, 533 US at 341-42 (Scalia dissenting) ("The Suspension Clause 
It seems all but concluded that any Suspension Clause challenge to $\S 2244$ (b) in isolation fails to pass jurisprudential muster. However, this doesn't necessarily mean that the section is blissfully free of constitutional infirmity.

\section{TOWARDS A RESOLUTION}

Every method taken by the courts-Cain's liberal approach, $P a$ netti's pragmatist twist thereupon, and Page's rigid focus on text and structure - is inadequate. The first two deviate from AEDPA's text to an unacceptable extent; the last risks denial of review of meritorious claims, and the foreclosure of any remedy. This Part answers two questions. First, does barring a remedy for a potential constitutional right violate the right itself? Second, if so, what are courts to do in such a situation?

\section{A. Foreclosed Remedies and Constitutional Rights}

The issue considered here is one of vindication of rights through remedies. A preliminary objection must be addressed before traveling any further. It may be contended that we need not worry about an inadequate or empty remedy, as this would merely signal that the potentially meritorious right is "underenforced" in this context. ${ }^{1.33}$ The outline of the right is discernable; courts apply it with ease in many situations. The fact of underenforcement for convicted prisoners who have already had one habeas petition adjudicated on the merits shouldn't cause too much turmoil, as rights and remedies-while related-are not a unity.

This outlook is not uncommon in academic circles. Some scholars have a propensity to speak of rights and remedies as if they inhabit two different planets - the former lounging in the Platonic world of forms, the latter holing up in the practical but cluttered corners of frantic courtrooms. One commentator notes, for example, that

[is not] a one-way ratchet that enshrines in the Constitution every grant of habeas jurisdiction."). Of course, a middle ground can be found between the Suspension Clause as a ratchet and the Suspension Clause as nothing other than a guarantee against full suspension. Scalia also expresses a view that the Suspension Clause pertains to only temporary abatements of the writ and nothing else. Id at 337-41 (noting that, in the case at issue, "Congress [had] not temporarily withheld operation of the writ, but [had] permanently altered its content").

182 See, for example, In re Vial, 115 F3d 1192, 1197-98 (4th Cir 1997) ("[T]he limitations imposed on second and successive $\S 2255$ motions by the AEDPA do not constitute a suspension of the writ.").

183 See Lawrence G. Sager, Fair Measure: The Legal Status of Underenforced Constitutional Norms, 91 Harv L Rev 1212, 1213 (1978) (arguing that "'underenforced' constitutional norms [should be treated] as valid to their conceptual limits"). 
[i]t is part of the intellectual fabric of constitutional law and its jurisprudence that there is an important distinction between a statement which describes an ideal which is embodied in the Constitution and a statement which attempts to translate such an ideal into a workable standard for the decision of concrete issues. ${ }^{184}$

But the two cannot be so cleanly separated. This Comment takes the view that "[r]ights are often shaped by the nature of the remedy that will follow if the right is violated." ${ }^{185}$ In order to fully understand the right, we must examine the remedy. ${ }^{186}$ One counterpoint here might be the existence of important-looking constitutional text that has begotten no or very few remedies - such as the Privileges or Immunities Clause of the Fourteenth Amendment. ${ }^{187}$ This, however, slightly misstates the approach. Rights do not entail remedies as a descriptive matter, insofar as for every right, there is a corresponding remedy. They entail remedies as a matter of definition. ${ }^{188}$ For all intents and purposes, the Privileges or Immunities Clause can scarcely be considered a part of the Constitution.

While this view may initially look radical, it bears a pedigree extending far into our jurisprudential tradition. Some of the most luminous stars in the Anglo-American judicial cynosure have been skeptical of the right-remedy division. William Blackstone, in his Commentaries on the Laws of England, ${ }^{189}$ opined that "it is a general and indisputable rule, that where there is a legal right, there is also a legal remedy, by suit or action at law, whenever that right is invaded." ${ }^{100}$ Later,

184 Id at 1213. See also Owen M. Fiss, Foreward: The Forms of Justice, 93 Harv L Rev 1, 51-52 (1979) ("The task of discovering the meaning of constitutional values ... is, however, quite different from choosing or fashioning the most effective strategy for actualizing those values."). These examples are provided in Daryl J. Levinson, Rights Essentialism and Remedial Equilibration, 99 Colum L Rev 857, 861 (1999) (describing "rights essentialism" as a view in which "[c]onstitutional adjudication ... begins with the identification or definition of the constitutional right, and only then proceeds to application of the right in a real world context").

185 Levinson, 99 Colum L Rev at 874 (cited in note 184).

186 Id at 880 ("Remedies are used by courts to define a constitutional standard that would otherwise be impossible to articulate, and those remedies become the normative criteria by which constitutional violations are judged.").

187 US Const Amend XIV, $\$ 1$ ("No state shall make or enforce any law which shall abridge the privileges or immunities of citizens of the United States.").

188 Note that a satisfactory excursus on this theoretical point falls well beyond the scope of this Comment. Robust arguments have been made on both sides of this debate, and this Comment lacks the space to address them all here. Suffice it to say that one side of the debate is fully advocated here - the side holding that rights and remedies cannot be separated. For an excellent discussion of this matter, see generally Levinson, 99 Colum L Rev 857 (cited in note 184).

189 William Blackstone, 3 Commentaries on the Laws of England (Chicago 1979).

190 Id at *23. This quote may be familiar to readers, as it is quoted by Justice John Marshall in Marbury v Madison, 5 US (1 Cranch) 137, 163 (1803). Marshall goes even further when he says that " $[\mathrm{t}]$ he very essence of civil liberty certainly consists in the right of every individual to claim the protection of the laws, whenever he receives an injury." Id. 
Learned Hand remarked that "a right without any remedy is a meaningless scholasticism." "[t]he prophecies of what the courts will do in fact, and nothing more pretentious, are what I mean by the law." ${ }^{102}$ Thus, it is purely idealistic to speak of "law" apart from its enforcement. "[A] legal duty so called is nothing but a prediction that if a man does or omits certain things he will be made to suffer in this or that way by judgment of the court;- and so of a legal right."

Scholars associated with the legal realist school have added to these general ideas. Karl Llewellyn echoed Holmes when he mentioned that "[w]hat [legal] officials do about disputes is, to my mind, the law itself." " Even more explicitly, he described the "cynic[al]" view as holding that

a right is best measured by effects in life. Absence of remedy is absence of right. Defect of remedy is defect of right. A right is as big, precisely, as what the courts will do. The differentiation between substantive law and adjective law is an illusion, although the prevalence of this illusion (as of any other) has results in human behavior, and must be taken account of. What the idealist calls substantive rights are not things, not even shadowy things; they are purposes the legal officials have set themselves: to get you to perform your agreement, to keep you off my land. But the law can be seen only in its effects.

Despite the pejorative connotation of the word "cynics," Llewellyn confesses that he is intellectually allied with them. Outside of the academic world, Supreme Court precedent also confirms that some remedy must be made available for the denial of a constitutional right. ${ }^{196}$

All this intellectual firepower leads to a very basic point. A constitutional right necessarily implies a remedy or it is undeserving of the name. If a constitutional right is not enforced by the courts, it either is not a right or it is a violation of constitutional text. As applied to the disagreement in the circuit courts, this principle dictates the

191 Wood \& Selick, Inc v Compagnie Generale Transatlantique, 43 F2d 941, 943 (2d Cir 1930).

192 Oliver Wendell Holmes, The Path of the Law, 10 Harv L Rev 457, 461 (1897).

193 Id at 458.

194 Karl N. Llewellyn, The Bramble Bush 12 (Oceana 1960).

195 Id at 83-84.

196 See, for example, Bivens v Six Unknown Named Agents of Federal Bureau of Narcotics, 403 US 388, 397 (1971) (finding that money damages were available for infringement of a plaintiff's Fourth Amendment rights). See also Zadvydas, 533 US at 690-96 (arguing that "an alien's liberty interest [was] strong enough to raise a serious question as to whether ... the Constitution permits detention that is indefinite"); St. Cyr, 533 US at 303-08 (determining that habeas allows courts to grant "discretionary relief" in, for example, the context of immigration disputes). 
conclusion that the interpretation of $\$ 2244(\mathrm{~b})$ as articulated in Cain is hermeneutically inadequate. ${ }^{197}$ While it can't be said that the preAEDPA abuse-of-the-writ interpretive arsenal is completely unavailable, the structural errors of that approach do not withstand scrutiny. However, the Page approach that properly accounts for the text and structure of the statute could vitiate and thus violate the Constitution. As such, neither can be considered an acceptable solution to the problem of $\S 2244$ (b).

\section{B. The Canon of Constitutional Avoidance}

As described above, the Cain approach to $\S 2244(\mathrm{~b})$ is textually promiscuous. The Page interpretation, in contrast, might pose serious constitutional questions in certain circumstances, which are not limited to those contemplated in Part V.A. The contours of this dilemma are not new to the courts. In fact, scholars and judges regularly rely on an interpretive goodie bag to deal with such quandaries. One such tool is the "canon of constitutional avoidance." 198 Louis Brandeis characterized it like this:

The Court will not pass upon a constitutional question although properly presented by the record, if there is also present some other ground upon which the case may be disposed of. ... Thus, if a case can be decided on either of two grounds, one involving a constitutional question, the other a question of statutory construction or general law, the Court will decide only the latter."

More recently, the Court has held that "where an otherwise acceptable construction of a statute would raise serious constitutional problems,

197 See notes 135-36 and accompanying text.

198 An early instance of this doctrine can be found in Murray v Schooner Charming. Betsy, 6 US (2 Cranch) 64, 118 (1804) ("[A]n act of Congress ought never to be construed to violate the law of nations if any other possible construction remains."), though the canon existed before Betsy was charmingly schooning about the seas, see Mossman v Higginson, 4 US (4 Dall) 12, 14 (1800) ("[T]he judiciary act can, and must, receive a construction, consistent with the constitution."). However, the canon is far from a dusty curiosity from a bygone age. See Clark $v$ Martinez, 543 US 371, 380-82 (2005) (articulating the canon of constitutional avoidance); Zadvydas, 533 US at 689 (same); St. Cyr, 533 US at 299-300 (same); United States v X-Citement Video, 513 US 64, 73 (1994) (same); United States v Thirty-Seven Photographs, 402 US 363, 369 (1971) (same). Despite its pedigree, the canon has its detractors. See, for example, Frederick Schauer, Ashwander Revisited, 1995 Sup Ct Rev 71, 74 (arguing that the canon leads to conclusions that a statute's drafters neither intended nor anticipated); Richard A. Posner, Statutory Interpretationin the Classroom and in the Courtroom, $50 \mathrm{U}$ Chi L Rev 800, 815-16 (1983) (remarking that the canon only enlarges a judge-made constitutional "penumbra").

199 Ashwander $v$ Tennessee Valley Authority, 297 US 288, 347 (1936) (Brandeis concurring). 
the Court will construe the statute to avoid such problems unless such construction is plainly contrary to the intent of Congress.",200

It cannot be denied, however, that neither AEDPA's text nor its legislative history speaks volumes about Congress's intent, and it is thus not at all clear what that intent is. Can it be said that the Fifth Circuit's interpretation in Cain is "plainly contrary" to the will of Congress? Here, Congress is not silent; it is just ambiguous. As the Supreme Court indelicately put it, "in a world of silk purses and pigs' ears, [AEDPA] is not a silk purse of the art of statutory drafting.",201 Also, as described above, whether AEDPA can be said to have a coherent purpose at all is far from clear. As such, it cannot be stated with great confidence that any interpretation-aside from those leading to patently absurd conclusions - is consonant with AEDPA's intent. The text is more or less all we have, and a straightforward reading of the text leads to potential constitutional problems in certain circumstances.

Courts should employ the canon of constitutional avoidance to revitalize pre-AEDPA principles as articulated in the courts following Cain. While the Cain method may be textually unfaithful-perhaps led astray by the uncertainty resulting from Martinez-Villareal-it does not lead to the foreclosure of review of constitutional rights, and the outcome can be tightened significantly. But if it fails to give effect to an act of Congress, it violates the Constitution. Textually unwarranted conclusions are not unprecedented in habeas jurisprudence,

200 Edward J. DeBartolo Corp v Florida Gulf Coast Building \& Construction Trades Council, 485 US 568, 575 (1988). See also Eskridge, Frickey, and Garrett, Legislation at 360-67 (cited in note 130) (detailing the canon of constitutional avoidance). Scholars have identified at least two separate strains of this canon. The first is deemed "classical avoidance," which posits that when a court is presented with two possible interpretations of an act, one constitutional and the other not, the constitutional reading should prevail. The other is deemed "modern avoidance." This is the formulation of DeBartolo. See Trevor W. Morrison, Constitutional Avoidance in the Executive Branch, 106 Colum L Rev 1189, 1202-04 (2006) ("The critical difference between classical and modern avoidance ... is in the level of constitutional concern needed to trigger the rule."); Adrian Vermeule, Saving Constructions, 85 Georgetown L J 1945, 1948-49 (1997) ("The basic difference between classical and modern avoidance is that the former requires the court to determine that one plausible interpretation of the statute would be unconstitutional, while the latter requires only a determination that one plausible reading might be unconstitutional."). The canon of constitutional avoidance, as discussed in this Comment, refers to the modern version. This is because it is not necessarily the case that the Cain set of courts presents an acceptable construction of AEDPA and the Page set presents an unconstitutional construction. Rather, the interpretation of the latter set of courts raises serious constitutional questions, and the former employs a questionable interpretive method. The tidiness envisioned by the classical version of the canon is simply not present here. This canon is not fully free from difficulty and can come into conflict with other interpretive methods. See id at 1946 (explicating a "severe reciprocal tension" between the canon of constitutional avoidance and the doctrine of severability). For a critique of the canon, see Schauer, 1995 Sup Ct Rev at 74 (cited in note 198) ("[T] he costs of [the canon] are greater than are commonly appreciated, and [ ] its benefits are becoming increasingly remote.").

201 Lindh v Murphy, 521 US 320, 336 (1997). 
especially when the alternative is a potential collision with the Constitution. $^{202}$ Resuscitating the abuse-of-the-writ doctrine to a level slightly beyond what is directly allowed by the text of $\S 2244$ (b) seems a much lesser price to pay than a direct constitutional attack on AEDPA's habeas provisions.

An infringement on a less central constitutional protection may call for a stricter interpretation of the text. Habeas corpus, however, is not a run-of-the-mill right. Holmes has said that "[i]t would indeed be a most serious thing if this court were [to deny habeas corpus review], for we could not but regard it as a removal of what is perhaps the most important guaranty of the Federal Constitution." ${ }^{203}$ The importance of the writ comes not from anything intrinsic to it, but rather the purpose it serves in vindicating other rights. Zechariah Chafee, Jr., did not include Holmes's apprehensive "perhaps." He described it unambiguously as " $[\mathrm{t}]$ he most important human rights provision in the Constitution." 204 again, its importance derives from the fact that "[t]his one human right is the safeguard of most other human rights."

The evil to be avoided in choosing one interpretation over the other is not the violation of one right, but the roadblock in front of a vehicle that is used to vindicate the entire panoply of constitutional rights. With this in mind, a mild textual departure seems a small price to pay for allowing habeas review of valid constitutional claims, and it is also a way to clarify the holding in Martinez-Villareal, and to apply it in a more principled manner to all claims not covered by Panetti.

The canon of constitutional avoidance has been applied to AEDPA before, ${ }^{206}$ but there is of course a danger in partially unmooring meaning from text. There is a great temptation to sever the two completely, and rely on whatever vague notion of "intent" the interpreter pre-

202 See, for example, St. Cyr, 533 US at 326 (finding that an immigration statute did not apply retroactively notwithstanding the statute's silence on the subject).

203 Frank v Mangum, 237 US 309, 348 (1915) (Holmes dissenting).

204 Zechariah Chafee, Jr., The Most Important Human Right in the Constitution, 32 BU L Rev 143, 143 (1952).

205 Id at 144.

206 See, for example, Triestman v United States, 124 F3d 361, 378-79 (2d Cir 1997) ("[W]e find that serious Eighth Amendment and due process questions would arise with respect to [ ] AEDPA if we were to conclude that, by amending $\$ 2255$, Congress had denied Triestman the right to collateral review in this case."). See also Note, The Avoidance of Constitutional Questions and the Preservation of Judicial Review: Federal Court Treatment of the New Habeas Provisions, 111 Harv L Rev 1578, 1579 (1998) (arguing that application of the avoidance canon to habeas cases under AEDPA is defensible, but may, ironically, limit habeas remedies in an attempt to sidestep the statutory restrictions). 
fers. ${ }^{207}$ It is therefore important to place limits on the reach of the canon's application.

Contrary to Cain, the abuse-of-the-writ doctrine is not fully resurrected. Petitioners who bring a claim in a second petition that could have been brought in the initial petition should be denied relief-it is not enough that they profess a reason for neglecting to bring it the first time. Only when a claim could not have been brought for lack of ripeness should the statutory text be ignored, and when foreclosure of review could lead to a violation of the underlying right by denying any possible judicial avenue for relief. This principle interacts with $\S 2244$ (b) in two ways. First, if a new rule of constitutional law is promulgated by the Supreme Court but not made retroactive to cases on collateral review, ${ }^{208}$ petitions should be allowed only when the decision makes it clear that a right could be violated if habeas review is cut off. Second, if a new factual predicate that was previously undiscoverable arises, but does not go to full innocence, the claim should be reviewed if a constitutional right would otherwise be violated. Note that these petitions are still "second or successive," $\S 2244(b)$ has been merely overridden in these peculiar circumstances to leave its constitutionality undisturbed.

If a second petition is allowed under this framework, the petitioner must bring all claims that are ripe at that time or risk losing them under the "modified res judicata" rule of abuse of the writ that has been partially disinterred. The most essential point is that a prisoner cannot use this approach for needless delay-it emphatically is not a jurisprudential snooze button that can be used to put off finality.

This approach will partially preserve the textual and structural analysis from Page, except in the cases when doing so would result in a constitutional violation. Furthermore, it will allow potentially meritorious claims to reach the federal courts, and in so doing will curtail dilatory petitions and preserve judicial resources. Lastly, it will encourage petitioners to bring all their available claims in their initial petitions, but leave them secure in the knowledge that, if a legitimate claim were to ripen, review would not be foreclosed.

207 For an example that poses the danger of potentially rootless interpretation, see Church of the Holy Trinity v United States, 143 US 457, 459 (1892) ("It is a familiar rule, that a thing may be within the letter of the statute and yet not within the statute, because not within its spirit, nor within the intention of its makers."). Panetti's interpretation of $\S 2244$ arguably applies this doctrine.

208 Again, Teague v Lane, 489 US 288 (1989), demands that certain types of cases automatically be made retroactive to cases on collateral review. Id at 307 . See also note 143 . But the Teague exceptions are manipulable and vague, and it's not out of the question that important rulings will not be made per se retroactive to cases that have completed direct review and passed into the collateral stages. 


\section{CONCLUSION}

AEDPA was passed by a divided government and under the threat of veto-as a result, the idea that it has a unitary and identifiable purpose is somewhat hard to defend. Its "gatekeeping" provisions prevent prisoners from filing petitions for habeas corpus that can be tagged as "second or successive," but this term goes undefined in the statutory text and has the potential to block legitimate attempts to seek habeas review.

A circuit split has developed over the interpretation of this section in the wake of Martinez-Villareal, with one group of courts applying the pre-AEDPA abuse-of-the-writ principles and the other relying more on the text and structure of the statute. The recent case of $\mathrm{Pa}$ netti resolves this issue with respect to Ford claims, but its scope is limited and its hermeneutic principles unsound. Both approaches taken by the circuit courts are unsatisfying-one ignores the statutory text, and the other could stand in the way of a prisoner's obtaining redress for a real constitutional harm. This Comment advocates using the canon of constitutional avoidance to remain faithful to the statutory text unless it would foreclose review of potential constitutional violations. In so doing, this approach avoids an uncompromising textualism that could deprive petitioners of a meaningful day in federal court, and also a wanton throwback to common law principles that ignore the plain import of the text. In the vast majority of cases, both can coexist. But when they cannot, it is AEDPA that must yield to habeas review, and not the other way around. 


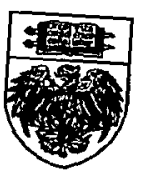

